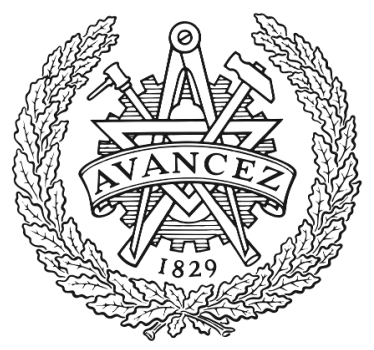

CHALMERS

UNIVERSITY OF TECHNOLOGY

\title{
Chemical-looping combustion of synthetic biomass-volatiles with manganese-ore oxygen carriers
}

Downloaded from: https://research.chalmers.se, 2023-04-26 10:03 UTC

Citation for the original published paper (version of record):

Moldenhauer, P., Sundqvist, S., Mattisson, T. et al (2018). Chemical-looping combustion of synthetic biomass-volatiles with manganese-ore oxygen carriers. International Journal of Greenhouse Gas Control, 71: 239-252. http://dx.doi.org/10.1016/j.ijggc.2018.02.021

N.B. When citing this work, cite the original published paper. 
This document is the Accepted Manuscript version of a Published Work that appeared in final form in Fuel Processing Technology, copyright (C) Elsevier after peer review and technical editing by the publisher. To access the final edited and published work see:

International Journal of Greenhouse Gas Control, 71: 239-252, 2018.

DOI: 10.1016/j.ijggc.2018.02.021

(C) 2018. This manuscript version is made available under the CC BY-NC-ND

4.0 license http://creativecommons.org/licenses/by-nc-nd/4.0/ 


\title{
Chemical-Looping Combustion of Synthetic Biomass-Volatiles with Manganese-Ore Oxygen Carriers
}

\author{
Patrick Moldenhauer ${ }^{\mathrm{a}, *}$, Sebastian Sundqvist ${ }^{\mathrm{b}}$, Tobias Mattisson $^{\mathrm{a}}$, Carl Linderholm ${ }^{\mathrm{a}}$ \\ ${ }^{a}$ Chalmers University of Technology, Department of Space, Earth and Environment, 41296 Gothenburg, Sweden \\ ${ }^{b}$ Chalmers University of Technology, Department of Chemistry and Chemical Engineering, 41296 Gothenburg, Sweden
}

\begin{abstract}
Carbon capture and storage of $\mathrm{CO}_{2}$ from combustion of biomass, i.e., bio-energy carbon capture and storage (BECCS), makes it possible to obtain so-called negative emissions - the atmosphere is cleansed from carbon dioxide. The purpose of the present study was to investigate the suitability of different manganese ores as oxygen carriers in chemical-looping combustion of biomass fuels. For this screening study, a laboratory-scale, circulating fluidized-bed CLC system with a nominal fuel input of $300 \mathrm{~W}_{\text {th }}$ was used. The primary focus was to investigate the reactivity of these oxygen carriers towards biomass fuels, and find a reactive oxygen carrier with sufficient mechanical stability that could be suitable for large-scale chemical-looping combustion of biomass. A synthetic "biomass volatiles" gas was used to study how the different gas components react with the oxygen-carrier particles. Additional experiments were conducted with methane and a syngas. Parameter studies concerning temperature and specific fuelreactor bed mass (bed mass per fuel thermal power in $\mathrm{kg} / \mathrm{MW}_{\mathrm{th}}$ ) were carried out. With the synthetic biomass volatiles, conversion of fuel carbon to $\mathrm{CO}_{2}$ as high as $97.6 \%$ was achieved. For a majority of the investigated ores, essentially all $\mathrm{C} 2$ and $\mathrm{C} 3$ hydrocarbons were converted, as well as a very high fraction of the $\mathrm{CO}$. Reactivity towards $\mathrm{CH}_{4}$ was generally lower, but improved at higher temperatures. The resistance of the oxygen carriers towards mechanical degradation was measured in a jet-cup attrition test rig. The measured attrition was estimated as "intermediate" for four of the five tested materials, while one of the ores displayed high attrition.
\end{abstract}

Keywords: chemical-looping combustion (CLC), biomass, manganese ore, $\mathrm{CO}_{2}$ capture, carbon capture and storage (CCS), BECCS

\section{Introduction}

\subsection{Chemical-Looping Combustion with Biomass}

Carbon capture and storage (CCS) has been recognized as a major option for climate change mitigation $[1,2]$. For $\mathrm{CO}_{2}$ capture, first generation technologies include pre-combustion, post-combustion and oxyfuel, which all require an active gas separation. Gas separation involves substantial investment and operational costs as well as significant energy penalties, estimated to be in the order of about $10 \%$-points of efficiency for a power plant $[3,4]$.

Chemical-looping combustion (CLC) is a combustion principle that uses metal oxides for oxygen transfer from air to fuel. Thus, fuel can be oxidized without mixing fuel and combustion air and the combustion products, i.e., $\mathrm{CO}_{2}$ and steam, are recovered in a separate flow without any active gas separation. After condensation of steam essentially pure $\mathrm{CO}_{2}$ is obtained. Thus, $\mathrm{CO}_{2}$ capture is inherent to the process and major costs and penalties for active gas separation are avoided. CLC is the only known $\mathrm{CO}_{2}$ capture technology where a very significant breakthrough could be envisaged regarding the costs and energy penalty of gas separation.

\footnotetext{
${ }^{*}$ Corresponding author. Telephone: +46(0)31-772 1469

E-mail address: patrick.moldenhauer@chalmers.se (Patrick Moldenhauer)
}

Combustion of biomass is $\mathrm{CO}_{2}$ neutral since biomass incorporates atmospheric $\mathrm{CO}_{2}$ during its growth via photosynthesis. If the CCS strategy is applied to biofuel emissions, negative emissions are effectuated - the air is cleansed from carbon dioxide. The combination of CCS and biofuel is referred to as BECCS - Bio-Energy Carbon Capture and Storage. Large-scale implementation of BECCS is presented by the IPCC (Intergovernmental Panel on Climate Change) not as a possibility, but as a necessity, if the global average surface temperature is to be limited to $2{ }^{\circ} \mathrm{C}$ [5]. The climate efficiency of BECCS is superior to other options for utilizing biomass. This is due to the fact that each fossil-based carbon molecule that is replaced with a biomass-based carbon molecule and BECCS, results in a net decrease of two carbon molecules from the atmosphere, i.e., one due to the replacement and one due to the removal from the atmosphere. If, in contrast, biomass is used for the production of liquid fuels for transport at a conversion rate of $50 \%$, the net decrease is only half a carbon molecule.

The fundamental principle of CLC is that a fuel is oxidized using two separate reactors: an air reactor (AR) and a fuel reactor (FR), as shown in Figure 1. A circulating flow of oxygen-carrier particles performs the task of transporting oxygen between these two reactors. Thus, direct contact between fuel and air is avoided, and, consequently, the combustion products $\mathrm{CO}_{2}$ and $\mathrm{H}_{2} \mathrm{O}$ are not diluted with $\mathrm{N}_{2}$. The reactor system can 
consist of two interconnected fluidized beds, the air reactor and the fuel reactor, with the oxygen carrier circulating between the two.

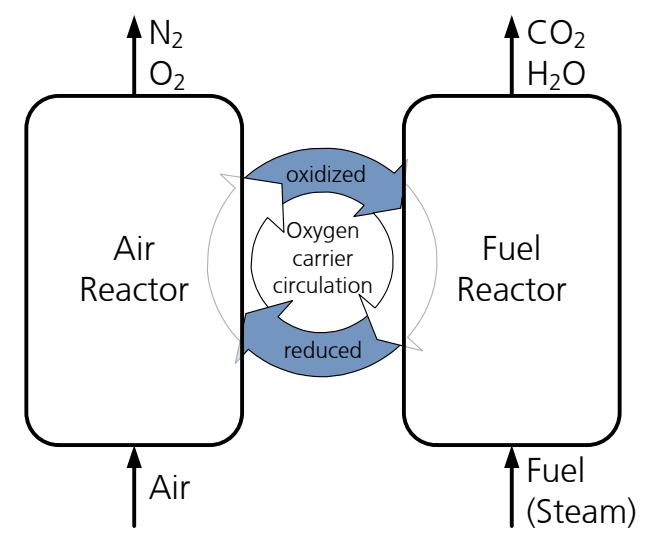

Figure 1: Schematic description of chemical-looping combustion process.

Most research efforts within chemical looping have focused on gaseous fuels, but in the last years work has been dedicated to adapting CLC to solid fuels. Lyngfelt presented a review on chemical-looping combustion with solid fuels [6], where it is shown that solid-fuel studies concerning use of coal are numerous, whereas studies dealing with biomass fuels are few. Biomass consists mainly of volatile components and a minor share of fixed carbon. The volatiles can react with the oxygen carrier as a "normal" gaseous fuel, and the char remaining after devolatilization is more reactive as compared to chars from coal or petcoke, due to (1) a porosity, (2) a higher content of oxygen and hydrogen and (3) a higher content and dispersion of catalytic ash components (e.g., $\mathrm{Ca}, \mathrm{K}, \mathrm{Na}$ ). Hence, higher solid fuel conversion as well as more effective $\mathrm{CO}_{2}$ capture can be expected with biomass than with coal or petcoke.

\subsection{Manganese-based Oxygen Carrier Materials}

Manganese-based oxygen carriers belong to a group of materials, which have the potential to release gas-phase oxygen in the fuel reactor. This oxygen release is triggered by differences in oxygen concentration and temperature between the air reactor and the fuel reactor. A chemical-looping process, where gas-phase oxygen is released in the fuel reactor is usually referred to as chemical-looping combustion with oxygen uncoupling (CLOU). In CLOU, the reactant, i.e., fuel, can react directly with gas-phase oxygen instead of the solid oxygen-carrier, as in regular CLC. For solid fuels, CLOU is potentially much faster than a solid-solid reaction as in CLC. But even for gaseous fuels, which includes volatiles, CLOU is expected to entail better conversion than CLC for three reasons [7];

1. Reactant gases that bypass the oxygen-carrier bed in bubbles can be oxidized by oxygen released on top of the bed. This applies especially in a bubbling fluidized-bed.

2. If the release of oxygen is fast, then normal combustion reaction occurs, which is likely to be faster than a gassolid reaction in CLC.
3. In regular CLC and for a first order reaction, full conversion of gaseous reactant is approached asymptotically at increased bed mass. In consequence relatively large bed masses are needed to convert the last remains of fuel. In CLOU, the oxygen release occurs independently of the reactant concentration, and consequently a much lower bed mass is required the reach full conversion.

\subsubsection{Existing Studies with Manganese ore-based Oxygen Car- riers}

There is a multitude of publications available that deal with the use of manganese ore-based oxygen-carrier materials in chemical-looping combustion.

In 2009, Leion et al. published an experimental investigation of three untreated manganese ores, four beneficiated manganese ores, as well as 12 iron-based materials that were tested in a batch, fluidized-bed reactor. They found that several of the mineral-, Mn-based materials showed good reactivity with both syngas and methane, but only one of these materials was able to fulfil the criteria for crushing strength and fluidization properties [8].

Based on experiments conducted in a batch reactor as well as in a TGA, Fossdal et al. found that the addition of $\mathrm{CaO}$ to manganese ore resulted in the formation of a calcium-manganite perovskite, which has potential positive effects on reactivity and structural integrity [9].

Linderholm et al. tested a manganese ore in continuous CLC operation in a $10 \mathrm{~kW}$ unit with a bituminous coal and a petcoke. As compared to ilmenite, the manganese ore achieved a significantly higher rate of fuel gasification and higher gas conversion, while fines production was higher [10]. In a consecutive study, the manganese ore was blended with $\mathrm{CaO}$, which led to an increase in conversion of solid fuel compared to unblended ore [11]. In the same unit, Schmitz et al. conducted tests with three Mn-based minerals with wood char and petcoke as fuels. All three minerals tested achieved a higher fuel conversion compared to ilmenite, while exhibiting a significantly lower lifetime [12].

Arjmand et al. and Frohn et al. compared a manganese ore to an ilmenite in a batch, fluidized-bed reactor with petcoke, bituminous coal and wood char as fuels. They found that steam gasification of char was significantly higher for the manganese mineral [13-15]. Keller et al. discovered that a transfer of potassium from $\mathrm{Mn}$ ore to petcoke takes place, which could be the reason for the increased rate of char gasification [16]. This effect was reproduced with different manganese ores by Arjmand et al. [15] and Mei et al. [17].

[18] manufactured oxygen carriers based on different manganese ores mixed with $\mathrm{Fe}_{2} \mathrm{O}_{3}$ and found that higher contents of iron are beneficial for conversion of petcoke. In a consecutive study, it could be shown that a calcium-manganite perovskite can be manufactured by mixing manganese ores with $\mathrm{Ca}(\mathrm{OH})_{2}$ [19].

$\mathrm{Xu}$ et al. could improve fuel conversion in a batch, fluidized-bed reactor dramatically by impregnating a manganese ore with as little as $0.5 \mathrm{wt} \%$ of copper [20]. Investigations in a laboratory-scale CLC reactor with continuous fuel feeding 
demonstrated that impregnation with copper does not affect the lifetime of the oxygen carrier measurably [21].

Haider et al. impregnated a manganese ore with $\mathrm{Fe}_{2} \mathrm{O}_{3}$ and an iron ore with $\mathrm{Mn}_{2} \mathrm{O}_{3}$ and conducted batchwise tests in a fluidized-bed reactor. Impregnation of the manganese ore reduced its reactivity towards methane and the syngas, while impregnating the iron ore improved its reactivity towards both fuels. Both ores exhibited an improved mechanical resistance after impregnation [22].

Sundqvist et al. tested 19 different manganese ores with methane and a syngas in batch operation and could show that nearly half of the manganese ores have a significantly higher reactivity with syngas as compared to ilmenite [23, 24]. Nearly all manganese ores tested exhibited a decrease in fuel conversion after three redox cycles at $1000{ }^{\circ} \mathrm{C}$.

Larring et al. performed a study of untreated samples of two $\mathrm{Fe}-\mathrm{Mn}$-based minerals, one Fe-based mineral and ilmenite. Tests were conducted in a TGA and it was found that costly pretreatment of minerals prior to utilization in a CLC process is not always necessary [25]. Ksepko et al. conducted further analysis with one of the $\mathrm{Fe}-\mathrm{Mn}$-based minerals and found that, as a function of temperature, Mn-rich particles exhibit a higher degree of disintegration than Fe-rich particles, while reactant concentration does not have a significant effect [26].

Investigations by Mei et al. in a batch, fluidized-bed reactor, showed that the reactivity of four heat-treated manganese ores decreased during the first ten redox cycles, after which reactivity remained nearly constant. Reactivity was high towards $\mathrm{CO} / \mathrm{H}_{2}$ and low towards $\mathrm{CH}_{4}$. During operation, particle size increased, while mechanical integrity decreased [27].

In a screening study, Perreault et al. tested 16 minerals, out of which four contained manganese, in a batch, fluidizedbed reactor. The oxygen transport capacity could be increased when the initial calcination was carried out in an oxidizing atmosphere [28].

Linderholm et al. tested a sintered manganese ore as oxygen carrier in continuous operation in a $100 \mathrm{~kW}$ CLC unit, with wood pellets [30], coal, petcoke and wood char [29] as fuel. In comparison to previously used iron-based oxygen carriers, this material showed higher gas conversion and lower loss of char to the air reactor, with carbon capture reaching as high as $100 \%$. In another test campaign in the $100 \mathrm{~kW}$ unit, the addition of up to $8 \mathrm{wt} \%$ of a manganese ore to ilmenite was found to significantly improve gas conversion when two different bituminous coals were used as fuels [31].

\subsection{Scope of Study}

The conversion of biomass in a chemical-looping process can be divided into three different parts, i.e., char conversion, volatile conversion and fate of mineral matter such as chlorine and alkali. Volatiles, which are released upon heating, are the main part of biomass - typically $80 \mathrm{wt} \%$ of the original fuel on a dry basis - and the focus of this study. A synthesized gas mixture was used to simulate biomass volatiles, which was tested with five different manganese ores - some of which also contained substantial amounts of iron - as oxygen carriers in a continuous CLC reactor system. Char conversion was assessed indirectly through testing with a syngas $\left(50\right.$ vol\% $\mathrm{H}_{2}$ in $\left.\mathrm{CO}\right)$. Char does usually not react directly with the oxygen carrier, but needs to be gasified first.

The aim of the project was to find a reactive oxygen carrier that could be suitable for large-scale application of CLC with biomass. Thus, the focus was on evaluating natural materials, where large amounts of particles can be obtained without the need for industrial granulation processes. This study is a continuation of the work by Sundqvist et al., who conducted a large screening study of 19 different manganese ores in a batch, fluidized-bed reactor [23, 24, 32]. Here, a laboratory-scale $300 \mathrm{~W}$ unit with continuous fuel feeding and continuous circulation of oxygen-carrier particles was used to evaluate the reactivity of five different manganese ores towards biomass volatiles. This bench-scale unit requires only a limited inventory of particles, $<0.5 \mathrm{~kg}$, but exposes the materials to hundreds of continuous redox cycles at high temperatures, which allows to study the effects of chemical-looping operation on the minerals.

\section{Experimental Details}

\subsection{Oxygen Carrier Materials}

In this study five different manganese ores were used as oxygen-carrier materials for chemical-looping combustion. In the following sections it is explained how they were prepared and characterized, and the experimental parameters investigated are shown.

\subsubsection{Selection and Characterization}

Suitable oxygen-carrier materials were identified in the first part of the project. Five minerals were characterized with ICPSFMS (inductively coupled plasma-sector field mass spectrometry) according to SS-EN ISO 17294-1,2 (mod) as well as EPA method 200.8 (mod), see Table 1 . The selection was made primarily based on different mass ratios of elements that are known to have a significant effect on the reactivity. Hence, Guizhou and Elwaleed $\mathrm{C}$ ores have high respectively very high ratios of Fe:Mn. Tshipi ore contains a lot of Ca, whereas Morro da Mina ore has a high $\mathrm{Si}: \mathrm{Mn}$ ratio. Braunite is a high-grade manganese ore.

All manganese ores, with the exception of Morro da Mina ore, have previously been investigated by Sundqvist et al. in a batch fluidized-bed reactor with a syngas and methane as fuel $[23,24]$. Out of these four ores, Tshipi ore had the highest reactivity towards $\mathrm{CO}$ and $\mathrm{CH}_{4}$, followed by Elwaleed $\mathrm{C}$ ore, while Guizhou and Braunite ores exhibited a somewhat lower reactivity. Tshipi and Guizhou ores were also tested with char and, again, Tshipi ore exhibited a higher reactivity [32]. Guizhou ore was part of a benchmarking study by Larring et al. [25], cf. Section 1.2.1, where Guizhou ore performed worse than the other manganese ore tested [25].

\subsubsection{Preparation}

In order to be used as oxygen carrier in a circulating fluidized-bed reactor the materials were heat treated, crushed and 
Table 1: Composition of materials used in this project determined with ICP-SFMS according to SS-EN ISO 17294-1,2 (mod) and EPA method 200.8 (mod). The balance of the "Total element + LOI" consists mainly of oxygen.

\begin{tabular}{|c|c|c|c|c|c|}
\hline Name of ore & $\begin{array}{l}\text { Elwaleed } \\
\text { (Grade C) }\end{array}$ & Tshipi & Guizhou & Braunite & Morro da Mina \\
\hline Producer & $\begin{array}{c}\text { Sinai } \\
\text { Manganese Co. }\end{array}$ & $\begin{array}{l}\text { Tshipi é Ntle } \\
\text { Manganese } \\
\text { Mining Ltd. }\end{array}$ & $\mathrm{n} / \mathrm{a}$ & $\begin{array}{c}\text { SCR- } \\
\text { Sibelco N.V. } \\
\text { (supplier) }\end{array}$ & $\begin{array}{c}\text { Vale } \\
\text { Manganes S.A. }\end{array}$ \\
\hline Country of origin & Egypt & South Africa & China & $\mathrm{n} / \mathrm{a}$ & Brazil \\
\hline Area & Sinai & $\begin{array}{l}\text { Kalahari Man- } \\
\text { ganese Field }\end{array}$ & Guizhou & $\mathrm{n} / \mathrm{a}$ & $\begin{array}{c}\text { Conselheiro Lafaiete, } \\
\text { Minas Gerais }\end{array}$ \\
\hline Mine & Abu Zenima & Tshipi Borwa & Songtao & $\mathrm{n} / \mathrm{a}$ & Morro da Mina \\
\hline $\mathrm{LOI}^{*}$ at $1000^{\circ} \mathrm{C}$ (mass $\left.\%\right)$ & 0.5 & 0.9 & 0.9 & 1.0 & 0.0 \\
\hline \multicolumn{6}{|c|}{ Elemental composition (mass $\%$ ) } \\
\hline $\mathrm{Mn}$ & 11.54 & 42.82 & 17.65 & 55.05 & 28.19 \\
\hline $\mathrm{Fe}$ & 51.74 & 5.38 & 28.60 & 16.22 & 6.58 \\
\hline $\mathrm{Si}$ & 4.59 & 4.41 & 7.33 & 3.17 & 15.26 \\
\hline $\mathrm{Al}$ & 1.27 & 0.20 & 7.36 & 0.17 & 4.99 \\
\hline $\mathrm{Ti}$ & 0.07 & 0.02 & 0.73 & 0.01 & 0.24 \\
\hline $\mathrm{Ca}$ & 0.82 & 10.86 & 0.20 & 2.42 & 2.24 \\
\hline $\mathrm{K}$ & 0.26 & 0.17 & 0.24 & 0.07 & 0.34 \\
\hline$M g$ & 0.39 & 2.33 & 0.57 & 0.38 & 1.74 \\
\hline $\mathrm{Ba}$ & 0.43 & 0.38 & 0.05 & 0.23 & 0.07 \\
\hline $\mathrm{Na}$ & 0.30 & 0.08 & 0.04 & 0.04 & 0.23 \\
\hline Total element & 71.6 & 66.7 & 62.9 & 77.8 & 60.1 \\
\hline \multicolumn{6}{|l|}{ Elemental ratios $(\mathrm{mol} / \mathrm{mol})$} \\
\hline $\mathrm{Fe} / \mathrm{Mn}$ & 4.41 & 0.12 & 1.59 & 0.29 & 0.23 \\
\hline $\mathrm{Si} / \mathrm{Mn}$ & 0.78 & 0.20 & 0.81 & 0.11 & 1.06 \\
\hline $\mathrm{Al} / \mathrm{Mn}$ & 0.22 & 0.01 & 0.85 & 0.01 & 0.36 \\
\hline $\mathrm{Ca} / \mathrm{Mn}$ & 0.10 & 0.35 & 0.02 & 0.06 & 0.11 \\
\hline $\mathrm{Mg} / \mathrm{Mn}$ & 0.08 & 0.12 & 0.07 & 0.02 & 0.14 \\
\hline$(\mathrm{Na}+\mathrm{K}) / \mathrm{Mn}$ & 0.09 & 0.01 & 0.02 & $<0.01$ & 0.04 \\
\hline References & {$[24]$} & {$[23,24,32]$} & {$[24,25,32]$} & {$[24]$} & \\
\hline
\end{tabular}

*LOI: loss on ignition, i.e., weight loss upon heating to $1000^{\circ} \mathrm{C}$ in air

sieved. A batch of green particles meant for use in the $300 \mathrm{~W}$ unit should consist of at least $450 \mathrm{~g}$, and since the unprocessed ores were available in limited quantities and had a wide size distribution, it was important to maximize the yield of particles in the desired size range. This was accomplished by adopting the following preparation scheme.

(1) Heat treatment $\left(950^{\circ} \mathrm{C}\right.$ for $24 \mathrm{~h}$ in air).

(2) Manual wet sieving with $90 \mu \mathrm{m}$ sieve.

(3) Drying (at $110^{\circ} \mathrm{C}$ ).

(4) Dry sieving with two sieves to obtain a size fraction of approximately $90-250 \mu \mathrm{m}$. Particles larger than $300 \mu \mathrm{m}$ were crushed in jaw crusher.

(5) Subjecting newly crushed material to Steps (2)-(4).

When necessary, Step (5) was repeated several times in order to obtain a sufficiently large batch of particles. In this way, it was possible to get a yield of more than $50 \mathrm{wt} \%$ in the range of $90-300 \mu \mathrm{m}$.

\subsection{Experiments in $300 \mathrm{~W}$ Unit}

The $300 \mathrm{~W}$ chemical-looping reactor is a laboratory unit designed for testing oxygen carriers under continuous circulation of particles and with continuous fuel feed. It should not be seen as a pilot plant suitable for upscaling. An illustration of the reactor, which was used in this work, is shown in Figure 2.

The reactor is $300 \mathrm{~mm}$ high. The fuel reactor has a crosssection of $25 \mathrm{~mm} \times 25 \mathrm{~mm}$. The base of the air reactor is $25 \mathrm{~mm} \times$ $42 \mathrm{~mm}$ and contracts to $25 \mathrm{~mm} \times 25 \mathrm{~mm}$ in the riser section. Fuel and air enter the system through separate windboxes, located in the bottom of each reactor. Porous quartz plates act as gas distributors. In the air reactor, the gas velocity is sufficiently high to create a circulating fluidized-bed and oxygen carrier particles are thrown upwards. The particle-gas mixture is then separated: oxygen depleted air is returned to the atmosphere, whereas a fraction of particles falls into the standpipe of the downcomer, which is the inlet of a J-type loop-seal. From the loop-seal, particles overflow into the fuel reactor via the return orifice. The fuel reactor is a bubbling-bed reactor. From the bottom of the fuel reactor, particles flow into the underflow standpipe of the slot, which is essentially a J-type loop-seal, and return to the air reactor, where the whole cycle starts over again.

The exit pipe of the fuel reactor is connected to a water seal with a column height of $1-2 \mathrm{~cm}$. As a result, the pressure in the 


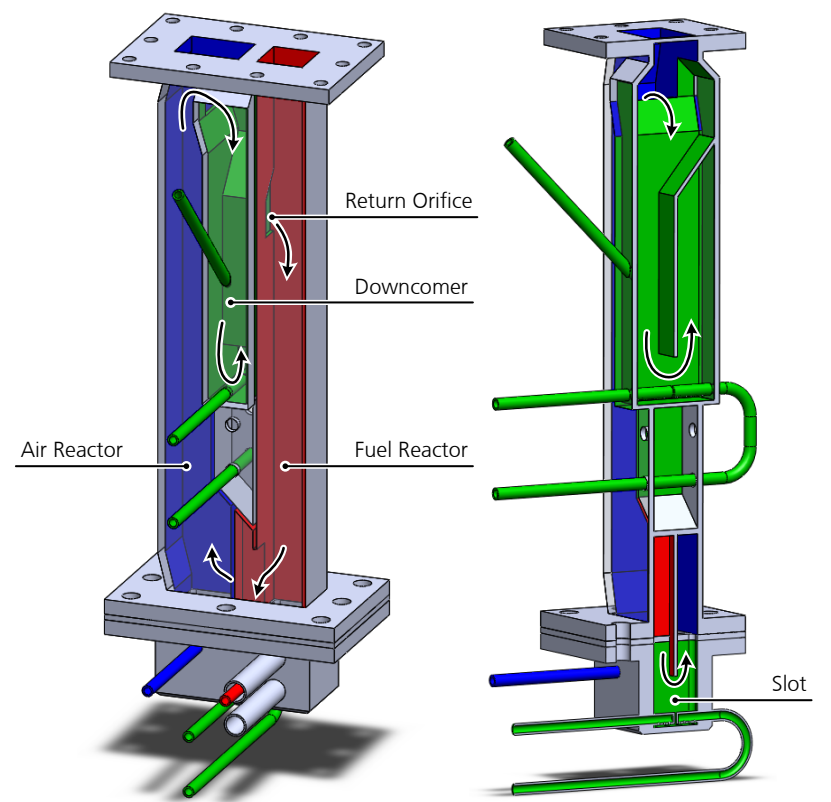

Figure 2: Schematic three-dimensional illustration of the $300 \mathrm{~W}$ chemical-looping reactor.

fuel reactor is $0.1-0.2 \mathrm{kPa}$ higher than in the air reactor, which reduces gas leakage from air reactor to fuel reactor.

Metal oxide $\left(\mathrm{M}_{x} \mathrm{O}_{y}\right)$ particles in the air reactor are fluidized with air, and reduced particles $\left(\mathrm{M}_{x} \mathrm{O}_{y-1}\right)$ are oxidized according to Reaction (R1). In the fuel reactor, the metal particles are fluidized by gas-phase fuel. Direct particle reduction occurs according to Reaction (R2). It is also possible that the particles react via CLOU, either fully or partially. Here, indirect oxygencarrier reduction and fuel oxidation proceed mainly according to Reactions (R3) and (R4), respectively.

$$
\begin{gathered}
\mathrm{M}_{x} \mathrm{O}_{y-1}+1 / 2 \mathrm{O}_{2} \longrightarrow \mathrm{M}_{x} \mathrm{O}_{y} \\
(2 m+n / 2) \mathrm{M}_{x} \mathrm{O}_{y}+\mathrm{C}_{m} \mathrm{H}_{n} \longrightarrow \\
\longrightarrow(2 m+n / 2) \mathrm{M}_{x} \mathrm{O}_{y-1}+m \mathrm{CO}_{2}+n / 2 \mathrm{H}_{2} \mathrm{O} \\
\mathrm{M}_{x} \mathrm{O}_{y} \longrightarrow \mathrm{M}_{x} \mathrm{O}_{y-1}+1 / 2 \mathrm{O}_{2} \\
\mathrm{C}_{m} \mathrm{H}_{n}+(m+n / 2) \mathrm{O}_{2} \longrightarrow m \mathrm{CO}_{2}+n / 2 \mathrm{H}_{2} \mathrm{O}
\end{gathered}
$$

The $300 \mathrm{~W}$ reactor is subject to high heat losses due to a high surface-to-volume ratio. To achieve sufficiently high temperatures, typically $800-950{ }^{\circ} \mathrm{C}$, the reactor is encased in an electric furnace.

\subsubsection{Fuels}

The synthetic biomass volatiles consisted of $\mathrm{CO}, \mathrm{H}_{2}, \mathrm{CH}_{4}$, $\mathrm{C}_{2} \mathrm{H}_{4}$ and $\mathrm{C}_{3} \mathrm{H}_{6}$. The mixture was chosen as to represent the gas generated during devolatilization of a wood-based biofuel. The composition of the gas can be found in Table 2. This composition resembles the gas generated during operation of the

\begin{tabular}{|c|c|c|c|}
\hline Component & $\begin{array}{c}\text { Fraction } \\
(\text { vol } \%)\end{array}$ & $\begin{array}{c}\text { Carbon fraction } \\
\text { (atomic \%) }\end{array}$ & $\begin{array}{c}\mathrm{LHV}^{*} \\
\left(\mathrm{MJ} / \mathrm{m}_{\mathrm{n}}^{3}\right)\end{array}$ \\
\hline $\mathrm{CO}$ & 43 & 55.1 & 12.6 \\
\hline $\mathrm{H}_{2}$ & 30 & - & 10.8 \\
\hline $\mathrm{CH}_{4}$ & 20 & 25.6 & 35.8 \\
\hline $\mathrm{C}_{2} \mathrm{H}_{4}$ & 6 & 15.4 & 59.0 \\
\hline $\mathrm{C}_{3} \mathrm{H}_{6}$ & 1 & 3.8 & 85.9 \\
\hline Total & 100 & 99.9 & 20.2 \\
\hline
\end{tabular}
Chalmers $2 \mathrm{MW}$ gasifier, with the exception that tars and other higher hydrocarbons have been removed [33]. The lower heating value of this fuel blend is $20.2 \mathrm{MJ} / \mathrm{m}_{\mathrm{n}}^{3}$.

Table 2: Composition of synthetic biomass volatiles.

*LHV: lower heating value, calculated based on data from [34]

The methane used had a purity of $99.5 \%$ and the syngas consisted of $50 \mathrm{vol} \%$ of $\mathrm{H}_{2}$ in $\mathrm{CO}$.

The fuel is added to the fuel reactor from below, and, hence, works also as fluidization agent in the reactor.

\subsubsection{Parameters Investigated}

Table 3 gives an overview over the different experiments, i.e., oxygen-carrier materials and fuels/CLOU, conducted in the $300 \mathrm{~W}$ unit. The specific settings investigated with the different manganese ores and synthesized biomass volatiles as fuel are shown in Table 4.

\subsection{Measurements}

During the experiments, measurements of pressure, temperature, gas flows and gas concentrations are logged continuously. Small streams of the flue gases from air reactor (AR) and fuel reactor $(\mathrm{FR})$, ca. $1 \mathrm{~L}_{\mathrm{n}} / \mathrm{min}$ on a dry basis, are diverted from the main gas streams, filtered, cooled to about $4{ }^{\circ} \mathrm{C}$ and fed to gas analyzers. Gas concentrations of $\mathrm{O}_{2}$ (paramagnetic sensor) and $\mathrm{CO}, \mathrm{CO}_{2}$ and $\mathrm{CH}_{4}$ (infrared sensors) are measured continuously in the flue gases from both reactor vessels.

A fraction of the dried gas stream of the fuel reactor is fed to a micro gas-chromatograph (GC) with two parallel columns (Molsieve MS5 $\AA, 10 \mathrm{~m} \times 0.32 \mathrm{~mm}$ and PoraPLOT Q, $10 \mathrm{~m} \times$ $0.15 \mathrm{~mm}$ ), which both are equipped with a thermal-conductivity detector. In the gas chromatograph, concentrations of $\mathrm{H}_{2}$, $\mathrm{N}_{2}, \mathrm{O}_{2}, \mathrm{CO}, \mathrm{CH}_{4}, \mathrm{CO}_{2}, \mathrm{C}_{2} \mathrm{H}_{n}$ and $\mathrm{C}_{3} \mathrm{H}_{n}{ }^{1}$ are detected and quantified intermittently.

\section{Data Evaluation}

\subsection{Fuel Conversion}

The evaluation of the conversion of carbon uses data from different analyzers, i.e., infrared analyzers and a gas chromatograph. Carbon fractions, $f_{\mathrm{C}, i}$, are calculated, which are the fractions of fuel carbon in the fuel reactor converted to $\mathrm{CO}, \mathrm{CO}_{2}$,

${ }^{1} \mathrm{C}_{2} \mathrm{H}_{n}$ and $\mathrm{C}_{3} \mathrm{H}_{n}$ are substitute denominations for hydrocarbons with two and three carbon atoms, respectively. This includes the species $\mathrm{C}_{2} \mathrm{H}_{2}, \mathrm{C}_{2} \mathrm{H}_{4}$ and $\mathrm{C}_{2} \mathrm{H}_{6}$ and $\mathrm{C}_{3} \mathrm{H}_{4}, \mathrm{C}_{3} \mathrm{H}_{6}$ and $\mathrm{C}_{3} \mathrm{H}_{8}$. 
Table 3: Experimental matrix for the different manganese ores and fuels used with duration of fuel addition shown. In a "CLOU" experiment, fuel is replaced by argon in order to measure the oxygen release.

\begin{tabular}{|c|c|c|c|c|c|}
\hline & CLOL & $\begin{array}{l}\text { Biomass } \\
\text { volatiles }\end{array}$ & Methane & Syngas & CLOU \\
\hline Elwaleed C & $x$ & $14.5 \mathrm{~h}$ & $3.9 \mathrm{~h}$ & $8.7 \mathrm{~h}$ & $x$ \\
\hline Tshipi & $\times$ & $13.6 \mathrm{~h}$ & 0 & $3.1 \mathrm{~h}$ & 0 \\
\hline Guizhou & $x$ & $11.4 \mathrm{~h}$ & $14.6 \mathrm{~h}$ & $6.0 \mathrm{~h}$ & 0 \\
\hline Braunite & $x$ & $15.7 \mathrm{~h}$ & $3.1 \mathrm{~h}$ & $9.8 \mathrm{~h}$ & $x$ \\
\hline Morro da Mina & $x$ & $7.3 \mathrm{~h}$ & 0 & 0 & 0 \\
\hline
\end{tabular}

Table 4: Experimental parameters investigated with biomass volatiles as fuel.

\begin{tabular}{|c|c|c|c|c|c|c|}
\hline & & Elwaleed C & Tshipi & Guizhou & Braunite & Morro da Mina \\
\hline Solids inventory, initial & $(\mathrm{g})$ & 380 & 310 & 330 & 400 & 280 \\
\hline Particle size (range), initial & $(\mu \mathrm{m})$ & $90-212$ & $90-212$ & $45-212$ & $45-250$ & $90-212$ \\
\hline Particle size (harmonic mean), initial & $(\mu \mathrm{m})$ & 141 & 134 & 122 & 148 & 137 \\
\hline Poured bulk density*, initial & $\left(\mathrm{kg} / \mathrm{m}^{3}\right)$ & 1640 & 1410 & 1380 & 1940 & 1360 \\
\hline Terminal velocity ${ }^{\dagger}, u_{\mathrm{t}}$ & $(\mathrm{m} / \mathrm{s})$ & 0.54 & 0.43 & 0.36 & 0.68 & 0.43 \\
\hline Superficial gas velocity in riser, $u_{0}$ & $(\mathrm{~m} / \mathrm{s})$ & 0.93 & 0.81 & 0.81 & 0.93 & $0.70-0.93$ \\
\hline Temperature in fuel reactor & $\left({ }^{\circ} \mathrm{C}\right)$ & $850-925$ & $850-925$ & $850-925$ & $850-950$ & $900-925$ \\
\hline Fuel input & $\left(\mathrm{W}_{\mathrm{th}}\right)$ & $260-350$ & 210-290 & $210-290$ & $280-370$ & $190-220$ \\
\hline $\begin{array}{l}\text { Specific fuel-reactor bed mass, } \\
\text { [fuel-reactor bed mass / fuel input] }\end{array}$ & $\left(\mathrm{kg} / \mathrm{MW}_{\mathrm{th}}\right)$ & $310-520$ & $230-360$ & $230-380$ & $270-410$ & $350-420$ \\
\hline
\end{tabular}

*measured on the basis of ISO 3923-1:2008

${ }^{\dagger}$ calculated for particles in initial state (with respect to bulk density and mean size) for fluidization in air at $900^{\circ} \mathrm{C}$

$\mathrm{CH}_{4}$ and hydrocarbons higher than $\mathrm{CH}_{4}(\mathrm{C} 2$ and $\mathrm{C} 3)$, see Equations (2)-(5). The term "yield" instead of fraction is used for the carbon fraction of $\mathrm{CO}_{2}, \gamma_{\mathrm{CO}_{2}}$, see Equation (1).

$$
\begin{aligned}
\gamma_{\mathrm{CO}_{2}} & =\frac{x_{\mathrm{CO}_{2}, \mathrm{FR}}}{x_{\mathrm{CO}_{2}, \mathrm{FR}}+x_{\mathrm{CO}, \mathrm{FR}}+\sum\left(m \cdot x_{\mathrm{C}_{m} \mathrm{H}_{n}, \mathrm{FR}}\right)} \\
f_{\mathrm{CO}} & =\frac{x_{\mathrm{CO}, \mathrm{FR}}}{x_{\mathrm{CO}_{2}, \mathrm{FR}}+x_{\mathrm{CO}, \mathrm{FR}}+\sum\left(m \cdot x_{\mathrm{C}_{m} \mathrm{H}_{n}, \mathrm{FR}}\right)} \\
f_{\mathrm{CH}_{4}} & =\frac{x_{\mathrm{CH}_{4}, \mathrm{FR}}}{x_{\mathrm{CO}_{2}, \mathrm{FR}}+x_{\mathrm{CO}, \mathrm{FR}}+\sum\left(m \cdot x_{\mathrm{C}_{m} \mathrm{H}_{n}, \mathrm{FR}}\right)}=\frac{\sum\left(2 \cdot x_{\mathrm{C}_{2} \mathrm{H}_{n}, \mathrm{FR}}\right)}{x_{\mathrm{CO}_{2}, \mathrm{FR}}+x_{\mathrm{CO}, \mathrm{FR}}+\sum\left(m \cdot x_{\mathrm{C}_{m} \mathrm{H}_{n}, \mathrm{FR}}\right)} \\
f_{\mathrm{C} 3} & =\frac{\sum\left(3 \cdot x_{\mathrm{C}_{3} \mathrm{H}_{n}, \mathrm{FR}}\right)}{x_{\mathrm{CO}_{2}, \mathrm{FR}}+x_{\mathrm{CO}, \mathrm{FR}}+\sum\left(m \cdot x_{\mathrm{C}_{m} \mathrm{H}_{n}, \mathrm{FR}}\right)}
\end{aligned}
$$

\subsection{Determination of Oxygen Carrier Circulation}

The design of the $300 \mathrm{~W}$ unit does not permit a direct measurement of the oxygen carrier circulation. Instead, there are two methods by which solids circulation can be indirectly measured. It should be stressed that both methods only give estimations of the solids circulation.

The circulation is a function of the fluidization velocity. Once the superficial gas velocity, $u_{0}$, i.e., the gas velocity that would result if the reactor vessel were empty, passes the terminal velocity, $u_{\mathrm{t}}$, particles are entrained and circulation commences. The relative velocity between gas and particle is called slip velocity $u_{\text {slip }}$, see Equation (6), and is, up to a point, proportional to the flow of solids. In order to make the slip velocity comparable for different materials it can be made dimensionless, see Equation (7). Since circulation is not directly measured during the experiments, the dimensionless slip velocity is used when comparing performance of different oxygen carrier materials. The terminal velocity, $u_{\mathrm{t}}$, is approximated according to Kunii and Levenspiel [35].

$$
\begin{aligned}
& u_{\text {slip }}=u_{0}-u_{\mathrm{t}} \\
& u_{\text {slip }}^{*}=\frac{u_{0}-u_{\mathrm{t}}}{u_{\mathrm{t}}}=\frac{u_{0}}{u_{\mathrm{t}}}-1
\end{aligned}
$$

\subsubsection{Reoxidation Method}

After fuel operation, the oxygen carrier particles in the fuel reactor are reoxidized. The amount of oxygen that is consumed during the reoxidation and the bed mass in the fuel reactor can be used to calculate the degree of mass-based conversion, $\omega$, where $m$ is the actual mass of the sample and $m_{\mathrm{ox}}$ is the mass of the fully oxidized sample, see Equation (8). Together with the amount of oxygen consumed in the air reactor before the reoxidation, i.e., during continuous operation, $\Delta \dot{m}_{\mathrm{O}_{2}, \mathrm{AR}}$, the circulation of solids, $\dot{m}_{\mathrm{s}}$, can be calculated according to Equation (9). Here, the underlying assumption is that the oxygen carrier is fully oxidized in the air reactor. 


$$
\begin{aligned}
\omega & =\frac{m_{\mathrm{OC}}}{m_{\mathrm{OC}, \mathrm{ox}}} \\
\dot{m}_{\mathrm{s}} & =\frac{\Delta \dot{m}_{\mathrm{O}_{2}, \mathrm{AR}}}{1-\omega}
\end{aligned}
$$

\subsubsection{Char Injection Method}

Another way of assessing the circulation of solids is to inject char, i.e., devolatilized coal, into the fuel reactor and to model the following $\mathrm{CO}_{2}$ profile in the air reactor using Equation (10) [36]. Here, $\left[\mathrm{CO}_{2}\right]_{\mathrm{AR}}$ is the measured concentration of oxygen in the air reactor, $a$ is a pre-exponential fitting factor, $t$ is the time during measurement of $\left[\mathrm{CO}_{2}\right]_{\mathrm{AR}}, N$ is the theoretic number of continuously stirred-tank reactors (CSTR) in series and $\tau$ is the total residence time of an average particle in a series of $N$ CSTRs.

$$
\left[\mathrm{CO}_{2}\right]_{\mathrm{AR}}=a \cdot t^{N-1} \cdot e^{-\frac{t}{\tau / N}}
$$

During the measurement the fuel reactor is fluidized with an inert gas, e.g., argon, and there is no other fuel added to the system. It is assumed that the char particles are well-mixed with the oxygen-carrier particles and travel through the system at the same rate as these particles.

The solids mass flow can be determined using Equation (11), where $m_{\text {bed,FR }}$ is the bed mass in the fuel reactor, which can be estimated by means of pressure-difference measurements over the bed.

$$
\dot{m}_{\mathrm{s}}=\frac{m_{\text {bed,FR }}}{\tau}
$$

\section{Results}

\subsection{Oxygen Release}

Oxygen release properties are determined by performing a temperature ramp, while fluidizing the fuel reactor with argon. The air reactor is fluidized with air. Thus, oxygen and nitrogen that leak from air reactor to fuel reactor can be differentiated from oxygen released from the particles by measuring $\mathrm{N}_{2}$.

Figure 3 shows curves fitted to the recorded concentrations of oxygen for all oxygen-carrier materials examined. Oxygen release properties were determined with "fresh" material, i.e., after heat treatment, and, in three out of five cases, after some hours of fuel operation. During these tests, the concentration of $\mathrm{O}_{2}$ at the outlet of the air reactor was similar for all materials and $19.5-21 \%$. From the figure it is clear that the propensity to release oxygen varies within a relatively wide range, although all materials showed some oxygen release properties.

Tshipi ore released about $1 \%$ of $\mathrm{O}_{2}$ at $900^{\circ} \mathrm{C}$ and the oxygen concentration did not change significantly with continuous redox cycles.

Guizhou ore has high oxygen release properties, i.e., about 3 vol\% in the dry-gas at $900{ }^{\circ} \mathrm{C}$. Oxygen release stability over continuous redox cycles was not investigated. However, relatively stable fuel conversion over more than $30 \mathrm{~h}$ gives reason

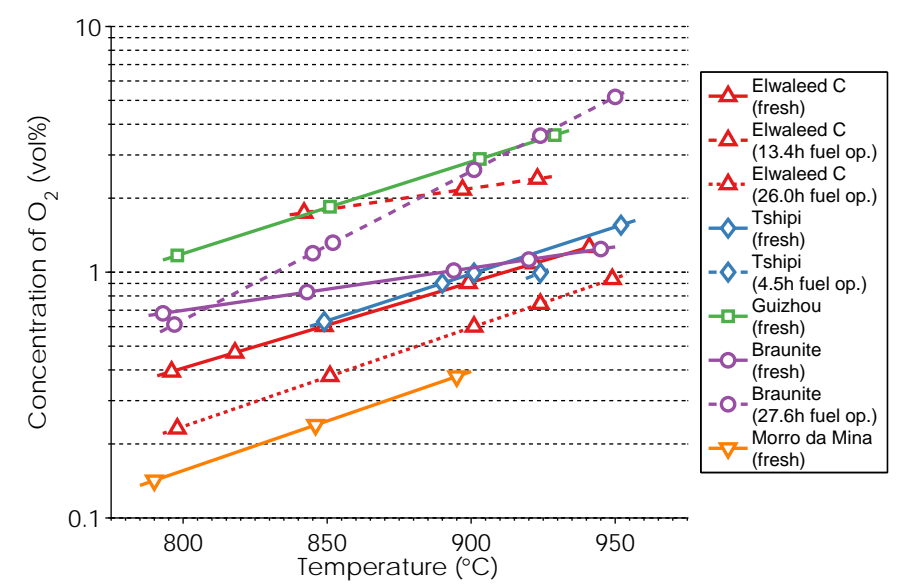

Figure 3: Oxygen release for all examined ores at varied temperature. The ores were tested in fresh state and after a period of fuel operation.

to believe that the oxygen release properties did not change significantly.

The oxygen release properties of Elwaleed $\mathrm{C}$ ore were investigated at three different points in time during the experimental campaign and they were found to be different each time. While fuel conversion with Elwaleed C ore was generally high, the change in oxygen release could explain the relatively high variation that is seen in Figure 5 in Section 4.2.1 below.

The oxygen concentration measured with Morro da Mina ore increased from $790{ }^{\circ} \mathrm{C}$ to $845^{\circ} \mathrm{C}$ to $895^{\circ} \mathrm{C}$, where it, after some time, fell to a significantly lower level, i.e., less than $0.1 \%$. After that, increasing the temperature to nearly $950^{\circ} \mathrm{C}$ and then reducing it to about $840{ }^{\circ} \mathrm{C}$ did not have a visible effect. It can be speculated that the material, at the beginning of the oxygen release experiment, contained phases, e.g., $(\mathrm{Mn}, \mathrm{Fe})_{2} \mathrm{O}_{3}$ (bixbyite), that provided a temperature-dependent oxygen release. However, once these phases released oxygen and were reduced, e.g., to $(\mathrm{Mn}, \mathrm{Fe})_{3} \mathrm{O}_{4}$ (spinel), the temperature in the air reactor was too high as to thermodynamically favor oxidation to $(\mathrm{Mn}, \mathrm{Fe})_{2} \mathrm{O}_{3}[37,38]$. The recorded data suggests that oxidation is possible at lower temperature, i.e., during cool-down respectively warm-up, though the high number of elements identified in the ore makes it difficult to support these observations with thermodynamic data.

Braunite ore exhibited originally low oxygen release properties, which, after a number of redox cycles, increased significantly and turned out to be, together with those of fresh Guizhou ore, the highest concentrations of oxygen of all materials tested in this study. Fresh Guizhou ore and used Braunite ore have in common the crystalline phase of $(\mathrm{Mn}, \mathrm{Fe})_{2} \mathrm{O}_{3}$ (bixbyite), cf. Table 5 in Section 4.3.2 below. This phase was also found in Elwaleed $\mathrm{C}$ ore (fresh and used state), but not in Tshipi ore or Morro da Mina ore. Hence, it seems likely, but it cannot be concluded distinctly, that the presence of $(\mathrm{Mn}, \mathrm{Fe})_{2} \mathrm{O}_{3}$ favors higher partial pressures of oxygen released compared to the other phases found. It should be stressed that even though oxygen is released from the oxygen carrier, the main mechanism of fuel conversion can still be via CLC [39]. In other 
words, a high CLOU effect is not a guarantee for high reaction rates.

\subsection{Fuel Conversion}

\subsubsection{Biomass Volatiles}

Figures 4 and 5 are comparisons of the fuel conversion performance of all five manganese ores investigated with biomass volatiles as fuel. $\mathrm{CO}_{2}$ yield and carbon fractions are shown at varied temperature, Figure 4, and at varied specific fuel-reactor bed mass, Figure 5. The dimensionless slip velocity in the riser is displayed for each group of data points as an indicator for the circulation of solids. Similar figures for the carbon fraction of C3 hydrocarbons are omitted, because no C3 species were detected within the parameters investigated.

With Tshipi ore, the highest investigated specific fuel-reactor bed mass and temperature yielded the maximum conversion of fuel carbon to $\mathrm{CO}_{2}$ of $97.6 \%$, see Figure $4 \mathrm{a}$. Virtually all $\mathrm{C} 2$ and $\mathrm{C} 3$ hydrocarbons were converted as well as a very high fraction of $\mathrm{CO}$. Reactivity towards $\mathrm{CH}_{4}$, on the other hand, was much lower, but improved significantly at higher temperatures and higher specific fuel-reactor bed masses, see Figures $4 \mathrm{c}$ and $5 c$. The conversion of hydrogen was high and increased with higher temperatures. The measured concentrations of hydrogen at $900{ }^{\circ} \mathrm{C}$ were below $1 \%$ at $230-260 \mathrm{~kg} / \mathrm{MW}_{\text {th }}$ and $0.5 \%$ and below at $350-360 \mathrm{~kg} / \mathrm{MW}_{\text {th }}$.

The maximum $\mathrm{CO}_{2}$ yield with Guizhou ore was $89.7 \%$ and was achieved at $900{ }^{\circ} \mathrm{C}$ and $380 \mathrm{~kg} / \mathrm{MW}_{\text {th }}$, see Figure $5 \mathrm{a}$. However, nearly the same $\mathrm{CO}_{2}$ yield was reached at $925^{\circ} \mathrm{C}$ and $340 \mathrm{~kg} / \mathrm{MW}_{\text {th }}$, see Figure $4 \mathrm{a}$. Nearly all hydrocarbon higher than $\mathrm{CH}_{4}$ was converted at temperatures above $850^{\circ} \mathrm{C}$. The levels of $\mathrm{CO}$ and $\mathrm{CH}_{4}$ were similar, the difference being that $\mathrm{CH}_{4}$ decreased with higher temperature, whereas $\mathrm{CO}$ increased slightly, see Figures $4 \mathrm{~b}$ and $4 \mathrm{c}$. A possible explanation could be that the reaction pathway from $\mathrm{CH}_{4}$ to $\mathrm{CO}_{2}$ passes $\mathrm{CO}$, in which the reaction rates of the different steps vary notably. Hence, when varying temperature, $\mathrm{CO}$ is expected to decrease once there is little or no $\mathrm{CH}_{4}$ left. Similar to the $\mathrm{CO}$ carbon-fraction, the amount of hydrogen in the fuel reactor increased in the temperature interval $850-925^{\circ} \mathrm{C}$; at $230-260 \mathrm{~kg} / \mathrm{MW}_{\text {th }}$ hydrogen concentration increased from $2 \%$ to $4 \%$ and at 310 $340 \mathrm{~kg} / \mathrm{MW}_{\text {th }}$ it increased from $1 \%$ to below $3 \%$. This again supports that methane is first converted to a syngas of $\mathrm{CO}$ and $\mathrm{H}_{2}$, which then reacts with the oxygen carrier. When the specific fuel-reactor bed mass was varied at $900{ }^{\circ} \mathrm{C}$ between $230 \mathrm{~kg} / \mathrm{MW}_{\text {th }}$ and $380 \mathrm{~kg} / \mathrm{MW}_{\text {th }}$, the $\mathrm{CO}_{2}$ yield increased nearly linearly, whereas the fractions of $\mathrm{CO}, \mathrm{CH}_{4}$ and $\mathrm{C} 2$ hydrocarbons decreased, see Figure 5.

Elwaleed $\mathrm{C}$ ore achieved high $\mathrm{CO}_{2}$ yields, although at specific fuel-reactor bed masses that were higher than those investigated with other manganese ores, see Figure 5a. The maximum $\mathrm{CO}_{2}$ yields were $96.9 \%$ and $96.3 \%$ and were observed at $900{ }^{\circ} \mathrm{C}$ and $520 \mathrm{~kg} / \mathrm{MW}_{\text {th }}$ and, respectively, at $925^{\circ} \mathrm{C}$ and $490 \mathrm{~kg} / \mathrm{MW}_{\text {th }}$ (not shown). $\mathrm{CH}_{4}$ decreased at higher temperatures, whereas $\mathrm{CO}$ remained nearly constant. The amount of unreacted $\mathrm{C} 2$ hydrocarbons at $850^{\circ} \mathrm{C}$ was higher than with the ores Tshipi and Guizhou with respect to the higher specific fuel-reactor bed mass. Above $900{ }^{\circ} \mathrm{C}$, however, nearly all twoatomic hydrocarbons were converted. The concentration of hydrogen remained nearly constant at $1 \%$. The effect of varying the specific fuel-reactor bed mass is most evident for low specific bed masses, i.e., between $310 \mathrm{~kg} / \mathrm{MW}_{\text {th }}$ and $380 \mathrm{~kg} / \mathrm{MW}_{\text {th }}$, where the $\mathrm{CO}_{2}$ yield increases dramatically from $63 \%$ to $93 \%$, see Figure $5 \mathrm{a}$. Above $380 \mathrm{~kg} / \mathrm{MW}_{\text {th }}$, the variation between the data points is high and a clear trend is not visible. The conversions of $\mathrm{CO}, \mathrm{CH}_{4}, \mathrm{C} 2$ hydrocarbons and $\mathrm{H}_{2}$ follow this pattern, i.e., they improve significantly up to $380 \mathrm{~kg} / \mathrm{MW}_{\text {th }}$, above which no clear trend is visible due to considerable variation between the data points.

With Braunite ore, the highest $\mathrm{CO}_{2}$ yield achieved was $87.8 \%$, see Figure 4a. Increasing temperature and/or specific bed mass increases the $\mathrm{CO}_{2}$ yield as well as the conversion of $\mathrm{CH}_{4}$ and $\mathrm{C} 2$ hydrocarbons. As was already observed for Elwaleed $\mathrm{C}$ ore, variation of temperature does not seem to effect the level of CO. The hydrogen concentration varied only slightly with temperature. At 310-330 kg/MW th and 360-390 kg/MW $\mathrm{MW}_{\text {th }}$, all $\mathrm{H}_{2}$ concentrations measured were around $3 \%$ and $2 \%$, respectively.

The results of the test campaign with Morro da Mina ore differ qualitatively from the results of the other ores tested for two reasons. (1) The available data for Morro da Mina ore is not sufficient to show the effect of varied temperature, see Figure 4. The reason for this is that fines production was high, which caused circulation problems before sufficient data could be recorded. (2) The effect of varied fluidization velocity expressed as dimensionless slip velocity, which can be seen in Figure 5, was not investigated for the other ores tested. Fuel conversion with Morro da Mina manganese ore was much lower than with the other manganese minerals investigated. The maximum $\mathrm{CO}_{2}$ yield was $82.6 \%$ (not shown here) and was observed at $925^{\circ} \mathrm{C}, 450 \mathrm{~kg} / \mathrm{MW}_{\text {th }}$ and a dimensionless slip velocity of 1.4. At higher fluidization velocities, the $\mathrm{CO}_{2}$ yield increases, while both $\mathrm{CO}$ and $\mathrm{CH}_{4}$ decrease. $\mathrm{C} 2$ hydrocarbons are low and show no clear trend. The hydrogen concentration decreased from $5 \%$ to $3 \%$. A variation of the specific fuel-reactor bed mass, which is shown in Figure 5, has only a small visible effect including hydrogen, which was approximately $4 \%$.

In lack of a better and comparable measurement, the dimensionless slip velocity is assumed to be more or less proportional to the solids circulation during the experiments. Ideally, the solids circulation would have been similar for the different oxygen-carrier materials tested, in order to have comparable conditions. Based on initial values of bulk density and particle size, cf. Table 4, the dimensionless slip velocities for the different ores tested were in the range of $0.4-1.3$, as most experiments were conducted with either $7 \mathrm{~L}_{n} / \mathrm{min}$ or $8 \mathrm{~L}_{\mathrm{n}} / \mathrm{min}$ of air in the air reactor. Throughout the experiments, however, bulk density and size distribution changed, cf. Table 6 , and the range of the dimensionless slip velocity increased to $0.4-2.3$.

The $\mathrm{CO}_{2}$ yield is highest for Elwaleed $\mathrm{C}$, Tshipi and Guizhou ore, which all achieved similar values. With regard to the slip velocity, Elwaleed $\mathrm{C}$ seems slightly more reactive than the other two. The $\mathrm{CO}_{2}$ yield for Braunite ore is much lower, but so is the slip velocity. It is possible that the $\mathrm{CO}_{2}$ yield could approach 


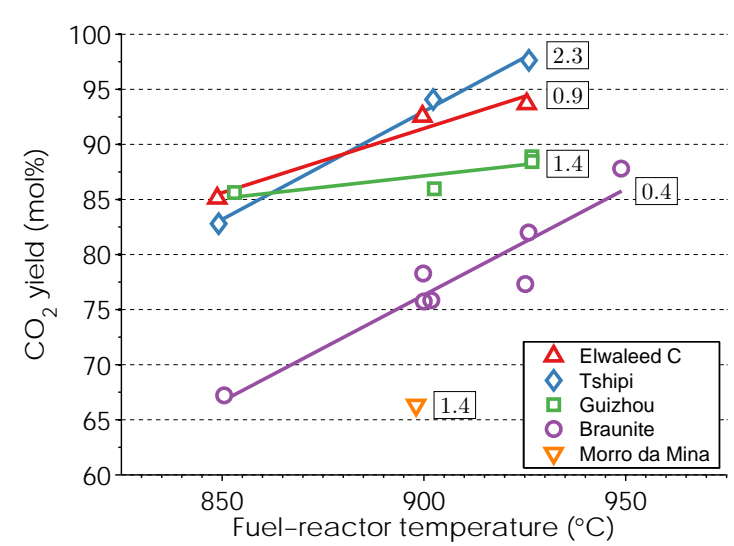

(a) $\mathrm{CO}_{2}$ yield

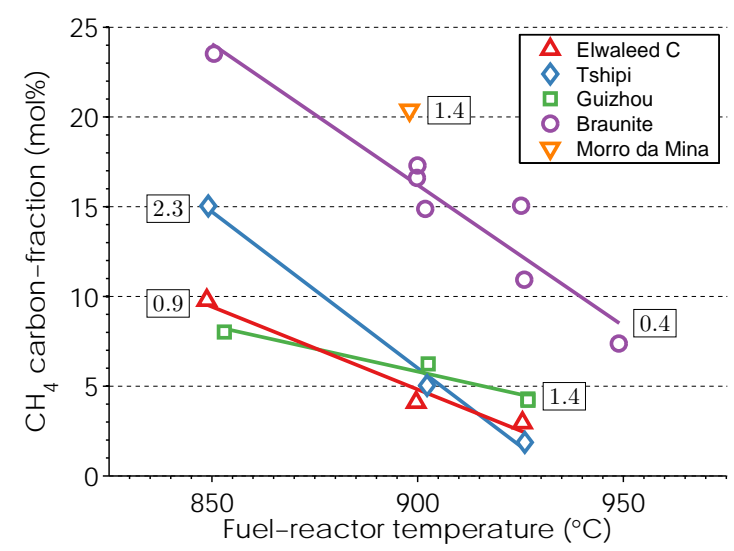

(c) $\mathrm{CH}_{4}$ carbon-fraction

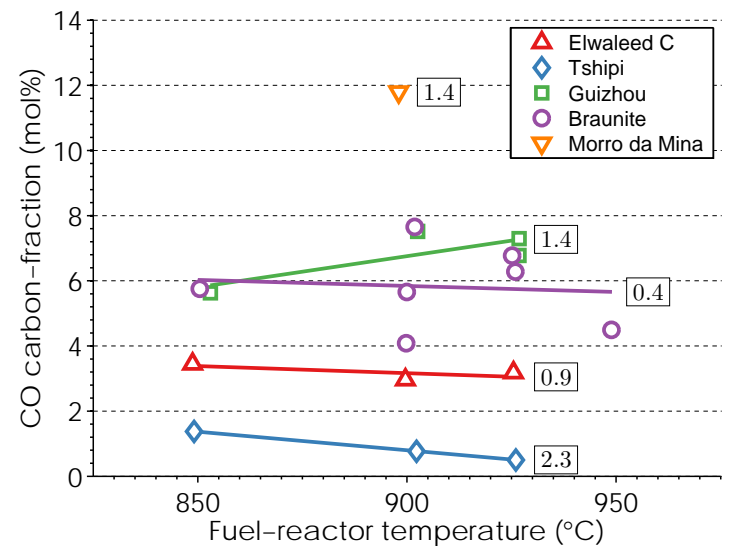

(b) CO carbon-fraction

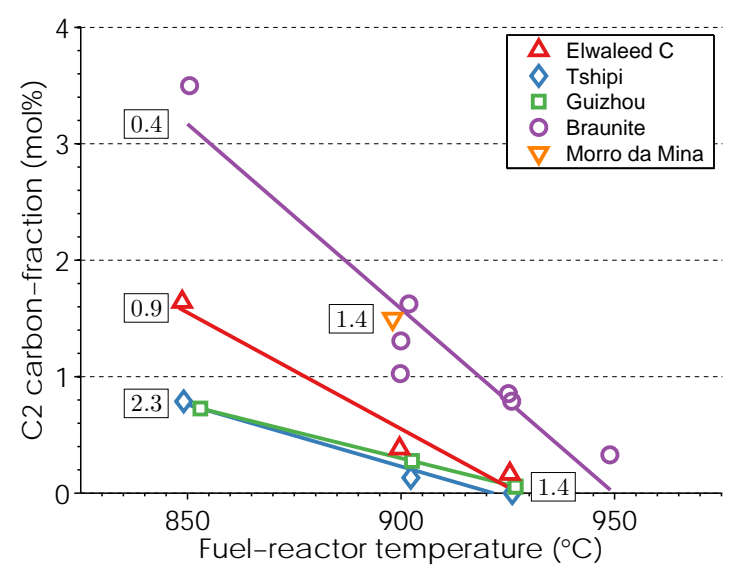

(d) $\mathrm{C} 2$ carbon-fraction

Figure 4: $\mathrm{CO}_{2}$ yield and carbon fractions for all examined ores at varied fuel-reactor temperature with biomass volatiles as fuel. The specific fuel-reactor bed masses are $380-390 \mathrm{~kg} / \mathrm{MW}_{\text {th }}$ for Elwaleed C ore, $350-360 \mathrm{~kg} / \mathrm{MW}_{\text {th }}$ for Tshipi ore, $310-340 \mathrm{~kg} / \mathrm{MW}_{\text {th }}$ for Guizhou ore, $360-390 \mathrm{~kg} / \mathrm{MW}_{\text {th }}$ for Braunite ore and $350 \mathrm{~kg} / \mathrm{MW}_{\mathrm{th}}$ for Vale da Mina ore. For each group of data points, the dimensionless slip velocity in the riser, $u_{\text {slip }}^{*}$, is shown in a box.

values close to those of Elwaleed C, Tshipi or Guizhou ore if the fluidization velocity was increased. Morro da Mina ore, however, achieved much lower $\mathrm{CO}_{2}$ yields, despite being subject to relatively high fluidization velocities.

Tshipi ore has the highest reactivity towards $\mathrm{CO}$, while that of Morro da Mina is lowest. With respect to the lower relative fluidization velocity, the reactivity of the Braunite ore towards $\mathrm{CO}$ could be potentially higher.

The carbon fractions of $\mathrm{CH}_{4}$ and $\mathrm{C} 2$ hydrocarbons show similar patterns; Elwaleed C, Tshipi and Guizhou ore have similar and high reactivity towards hydrocarbons. The reactivities of Morro da Mina ore and Braunite ore are much lower, but due to the lower relative fluidization velocity, the reactivity of Braunite ore might be comparable to that of Elwaleed C, Tshipi ore Guizhou ore.

In order to estimate to what extent circulation in a continuous unit influences reactivity, the following information is needed; (1) solids circulation and the degree of mass-based conversion during fuel addition in the continuous unit and (2) reactivity as a function of mass-based conversion, e.g., from batch experiments. Here, reactivity data is available for Tshipi, Guizhou, Elwaleed $\mathrm{C}$ and Braunite ores with both methane and syngas $[23,24]$. Based on these studies and when considering the degrees of mass-based conversion, $\omega$, cf. Table 7, Tshipi ore exhibits the highest reactivity towards $\mathrm{CO}$, followed by Braunite, Elwaleed $\mathrm{C}$ and Guizhou ores. This matches the results of this work for Tshipi ore, which displayed the highest levels of conversion with biomass volatiles and syngas. Tests with methane were not performed with Tshipi ore.

\subsubsection{Methane}

Fuel conversion of methane was investigated with Elwaleed C, Guizhou and Braunite ores. Fuel conversion for the different materials is shown as $\mathrm{CO}_{2}$ yield at varied specific fuel-reactor bed mass and at different fuel-reactor temperatures, see Figure 6. Guizhou ore has a clearly higher reactivity towards methane than Elwaleed $\mathrm{C}$ and Braunite, which exhibited similar reactivities. The highest $\mathrm{CO}_{2}$ yield observed was $72 \%$ and was observed with Guizhou ore at $925^{\circ} \mathrm{C}$ and $337 \mathrm{~kg} / \mathrm{MW}_{\text {th }}$. At a similar temperature, Elwaleed $\mathrm{C}$ and Braunite achieved 


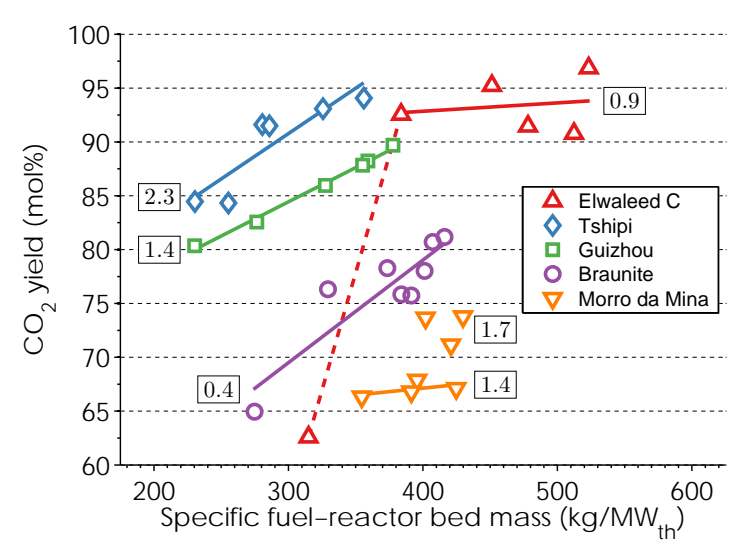

(a) $\mathrm{CO}_{2}$ yield

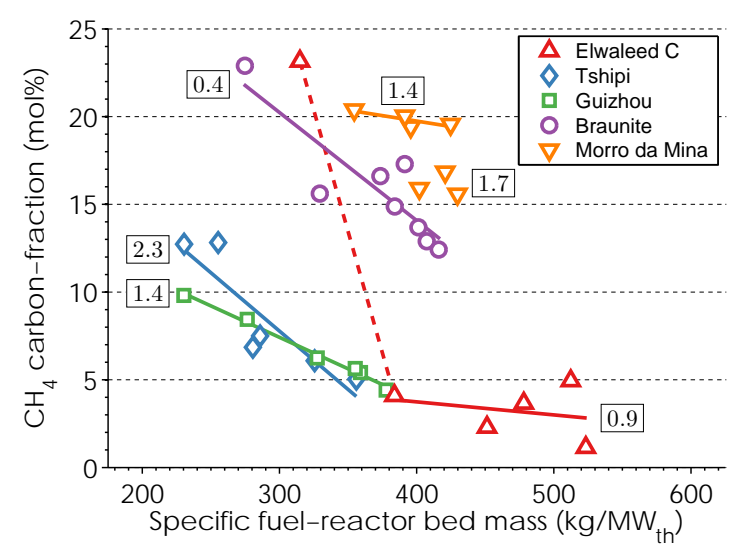

(c) $\mathrm{CH}_{4}$ carbon-fraction

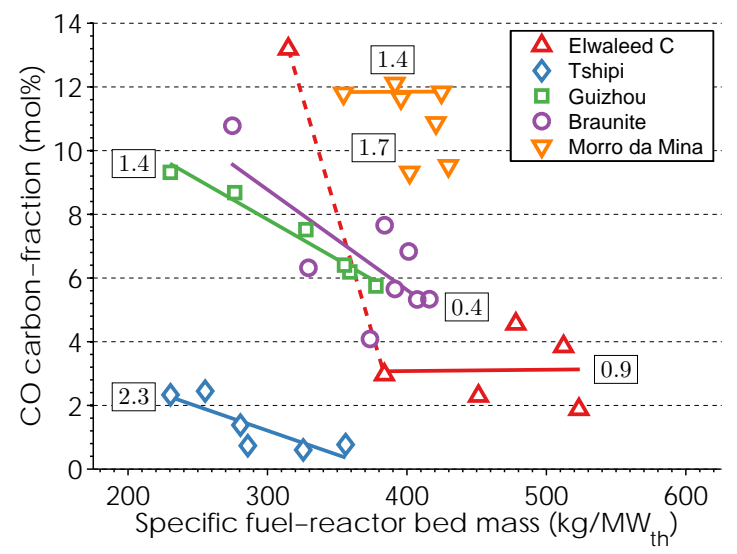

(b) CO carbon-fraction

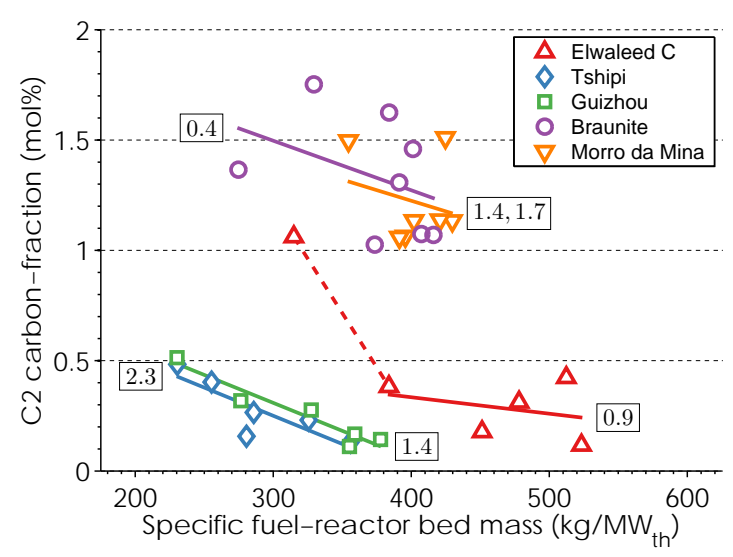

(d) $\mathrm{C} 2$ carbon-fraction

Figure 5: $\mathrm{CO}_{2}$ yield and carbon fractions for all examined ores at varied specific fuel-reactor bed mass at a fuel-reactor temperature of $900{ }^{\circ} \mathrm{C}$ with biomass volatiles as fuel. For each group of data points, the dimensionless slip velocity, $u_{\mathrm{slip}}^{*}$, is shown in a box.

$62 \%$ at $437 \mathrm{~kg} / \mathrm{MW}_{\text {th }}$ and $59 \%$ at $397 \mathrm{~kg} / \mathrm{MW}_{\text {th }}$, respectively. A trend can be seen that methane conversion rises with temperature. The most dramatic change occurred with Guizhou ore between $900{ }^{\circ} \mathrm{C}$ and $925^{\circ} \mathrm{C}$, where the $\mathrm{CO}_{2}$ yield increased by about $20 \%$-points.

The $\mathrm{CO}_{2}$ yield for methane is generally much lower as compared to biomass volatiles. A reason for that is likely a difference in reactivity of the oxygen-carrier material towards methane and the components of biomass volatiles, i.e., mostly $\mathrm{CO}$, cf. Table 2. Sundqvist et al. showed that the reactivity of manganese ores towards $\mathrm{CH}_{4}$ is generally lower than reactivity towards $\mathrm{CO}[23,24,32]$. In their experiments, at values of massbased conversion above 99.5 mass\%, Tshipi ore exhibited the highest reactivity followed by Elwaleed C, Braunite and Guizhou ores. This is the opposite of what was observed here. This discrepancy could be a consequence of ageing - the methane tests were carried out after the tests with biomass volatiles -, which could cause variations in reactivity.

\subsubsection{Syngas}

The ores Elwaleed C, Tshipi, Guizhou and Braunite were tested with syngas. Figure 7 shows the $\mathrm{CO}_{2}$ yield for the dif-

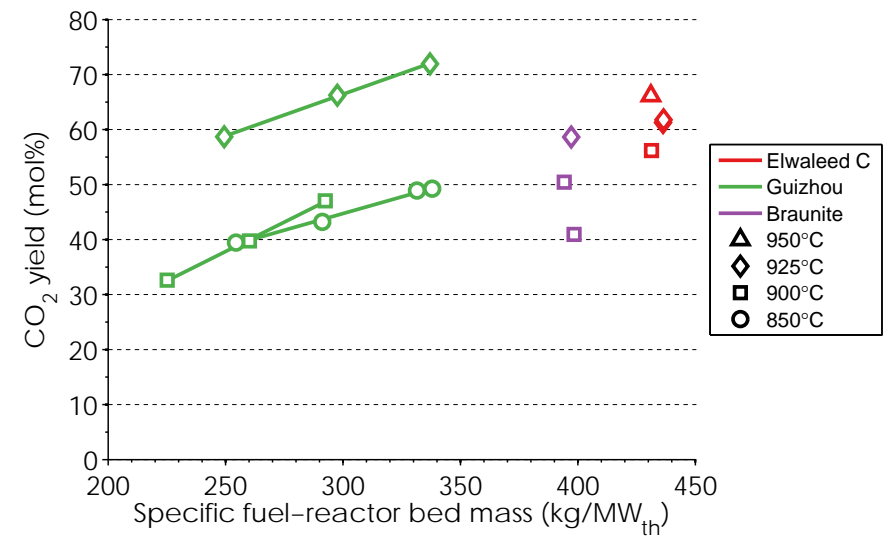

Figure 6: $\mathrm{CO}_{2}$ yield at varied specific fuel-reactor bed mass at different fuel-reactor temperatures with methane as fuel. Fitted lines are shown for Guizhou ore. Morro da Mina ore and Tshipi ore were not tested with methane.

ferent ores at varied specific fuel-reactor bed mass and different fuel-reactor temperatures. Generally, reactivity towards $\mathrm{CO}$ is much higher than towards $\mathrm{CH}_{4}$. For all materials and conditions 
tested, the $\mathrm{CO}_{2}$ yield with syngas as fuel was never below $80 \%$, whereas the $\mathrm{CO}_{2}$ yield with methane was never above $80 \%$. The single highest $\mathrm{CO}_{2}$ yield was achieved with Braunite ore, i.e., $98 \%$ at $371 \mathrm{~kg} / \mathrm{MW}_{\text {th }}$. However, as compared to the other ores tested, the specific fuel-reactor bed mass as well as the variance of the data points were significantly higher with Braunite ore. Even though Braunite ore achieved the single highest $\mathrm{CO}_{2}$ yield, it seems less reactive towards $\mathrm{CO}$ than the other ores at comparable conditions, i.e., temperature and specific fuel-reactor bed mass. The highest reactivities were exhibited by Tshipi and Guizhou ores. The data in Figure 7 suggests that Elwaleed $\mathrm{C}$ ore is less reactive at $925^{\circ} \mathrm{C}$ than at $900{ }^{\circ} \mathrm{C}$, which is unlikely. Instead, the pattern observed could be a consequence of material degradation with fuel operation time. The experiment at $925^{\circ} \mathrm{C}$ was conducted during the last day of the syngas test series, followed only by a concluding CLOU test, cf. Table 3 . During this last CLOU test, i.e., after $26 \mathrm{~h}$ of fuel operation, considerably less oxygen was released than during previous oxygen release tests with Elwaleed C, cf. Figure 3. Furthermore, a decrease in reactivity for Elwaleed $\mathrm{C}$ ore at $925^{\circ} \mathrm{C}$ is seen neither with biomass volatiles nor with methane, cf. Figures 4 and 6.

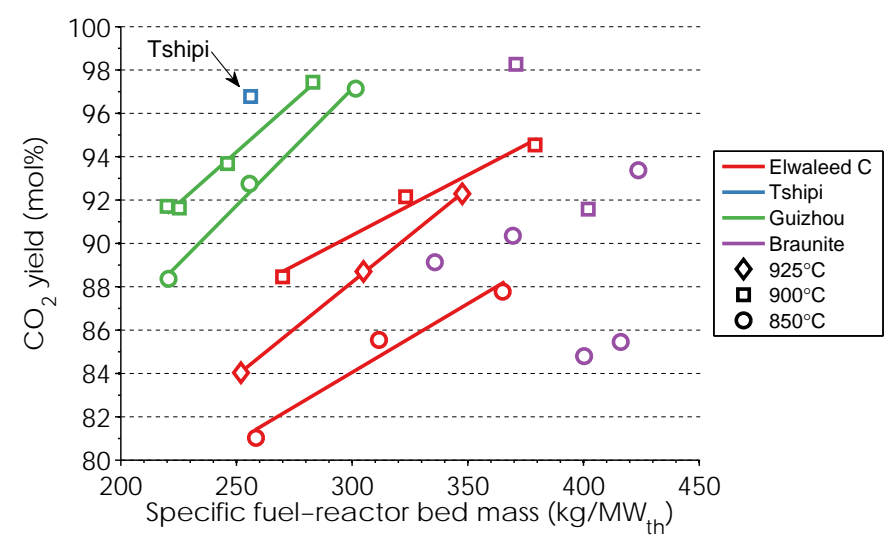

Figure 7: $\mathrm{CO}_{2}$ yield at varied specific fuel-reactor bed mass at different fuel-reactor temperatures with syngas as fuel. Fitted lines are shown for Elwaleed C ore and Guizhou ore. Morro da Mina ore was not tested with syngas.

The $\mathrm{CO}_{2}$ yield with syngas as fuel is generally higher than with biomass volatiles. As mentioned in Section 4.2.2, manganese ores have generally a higher reactivity towards $\mathrm{CO}$ than towards $\mathrm{CH}_{4}$. Consequently, with respect to carbon species, a mixture of methane and carbon monoxide, as in biomass volatiles, achieves a lower conversion than carbon monoxide in syngas. The molar fractions of $\mathrm{H}_{2}$ at the outlet of the fuel reactor were similar for each manganese ore between syngas and biomass volatiles at similar conditions. Hence, with respect to hydrogen conversion no clear conclusions can be drawn.

\subsection{Particle Analysis}

The following physical properties of the oxygen carrier particles were determined: (1) morphology (light microscope), (2) crystalline phase composition (X-ray powder diffraction, XRD), (3) size distribution (sieving), (4) density (bulk density measurements on the basis of ISO standard 3923-1) and (5) me- chanical strength (attrition resistance measured in a customized jet-cup attrition rig [40]).

\subsubsection{Appearance}

Figure 8 shows light microscope images taken before and after a test campaign. The images of the inserted material show heat treated material in a size fraction of $45-212 \mu \mathrm{m}$ or 90 $212 \mu \mathrm{m}$, cf. Table 4 . The images taken after a test campaign show unsieved material recovered from the reactor.

Elwaleed $\mathrm{C}$ particles became visibly rounder in the process. Almost no fines are visible in the used sample.

Tshipi ore underwent dramatic changes and was subject to severe disintegration. The used material contains a large fraction of small particles and fragments.

Very few fines are visible among the used Guizhou ore.

The Braunite ore particles became much rounder during the experiments. Nearly no fines are visible in the used sample.

Morro da Mina particles have a very distinct color, which differentiates them from the other ores examined. The heat treated particles have a red/yellow tone and the used material is nearly all yellow. A substantial fraction of smaller particles is clearly visible in the used sample.

\subsubsection{Phase Composition}

Crystalline phases of oxygen-carrier particles were identified using X-ray powder diffraction (Bruker D8 Advance) with $\mathrm{CuK} \alpha$ radiation. The lower detection limit was approximately 1 mass $\%$. The diffractograms of fresh and used particles were analyzed in the range of $2 \theta=15 \ldots 95^{\circ}$. The most frequently found phases in the heat treated manganese ores are $(\mathrm{Mn}, \mathrm{Fe})_{2} \mathrm{O}_{3}$ $(\mathrm{Mn}, \mathrm{Fe})_{3} \mathrm{O}_{4}, \mathrm{Fe}_{3} \mathrm{O}_{4}, \mathrm{Mn}_{7} \mathrm{SiO}_{12}$ and $\mathrm{SiO}_{2}$. The presence of major, unidentified peaks was common. The only clear difference to the used manganese ores is that the fractions of braunite-I and -II had decreased or disappeared in almost all cases; the exception being Morro da Mina, which was exposed to redox conditions less than half of the time compared to the other ores, $\mathrm{cf}$. Tables 3 and 7. Table 5 shows an overview of the main phases detected. Other phases were found, but only in trace concentrations, which made a comparison with the database uncertain.

\subsubsection{Attrition Resistance}

For comparison of different oxygen-carrier materials, the amount of fines produced in the chemical-looping reactor, i.e., particles smaller than $45 \mu \mathrm{m}$, as well as the total time of fuel operation are used. The fraction of fines includes both fines elutriated and captured in filters as well as fines retained in the reactor. Not the entire bed mass originally filled into the reactor could be recovered. The fraction that was not recovered could potentially also be fines that are stuck to the inside of metallic tubes.

The attrition measured with the jet-cup attrition rig quantifies the resistance the particles to mechanical stress (the measurement takes places at room temperature in air). The attrition observed in the reactor over the course of a test campaign, however, is a measure of the particles' resistance to chemical stress as mechanical stresses in the $300 \mathrm{~W}$ unit are believed to play 
Table 5: Main crystalline phases identified by XRD in fresh, i.e., heat treated, and used samples of the different manganese ores used.

\begin{tabular}{|c|c|c|}
\hline & Fresh (heat treated) & Used \\
\hline Elwaleed C & $\begin{array}{l}(\mathrm{Mn}, \mathrm{Fe})_{2} \mathrm{O}_{3} / \mathrm{Fe}_{2} \mathrm{O}_{3}{ }^{*}, \quad(\mathrm{Mn}, \mathrm{Fe})_{3} \mathrm{O}_{4} \\
\mathrm{CaMn}_{14} \mathrm{SiO}_{24}, \text { amorphous, unidentified }\end{array}$ & $\overline{(\mathrm{Mn}, \mathrm{Fe})_{2} \mathrm{O}_{3} / \mathrm{Fe}_{2} \mathrm{O}_{3},(\mathrm{Mn}, \mathrm{Fe})_{3} \mathrm{O}_{4}, \mathrm{SiO}_{2} \text {, unidentified }}$ \\
\hline Tshipi & $(\mathrm{Mn}, \mathrm{Fe})_{3} \mathrm{O}_{4}, \mathrm{Mn}_{7} \mathrm{SiO}_{12}, \mathrm{SiO}_{2}, \mathrm{CaO}$, unidentified & $(\mathrm{Mn}, \mathrm{Fe}) \mathrm{O} / \mathrm{CaO}, \mathrm{Fe}_{2} \mathrm{O}_{3}$, unidentified ${ }^{\dagger}$ \\
\hline Guizhou & $(\mathrm{Mn}, \mathrm{Fe})_{2} \mathrm{O}_{3} / \mathrm{Fe}_{2} \mathrm{O}_{3}{ }^{*}, \mathrm{Fe}_{3} \mathrm{O}_{4} / \mathrm{Mn}_{2} \mathrm{AlO}_{4}, \mathrm{Mn}_{7} \mathrm{SiO}_{12}{ }^{*}$ & $\begin{array}{l}(\mathrm{Mn}, \mathrm{Fe})_{2} \mathrm{O}_{3} / \mathrm{Fe}_{2} \mathrm{O}_{3}{ }^{*}, \quad(\mathrm{Fe}, \mathrm{Si})_{3} \mathrm{O}_{4} / \mathrm{Mn}_{2} \mathrm{AlO}_{4}, \\
\mathrm{Mn}_{2} \mathrm{O}_{3}{ }^{*}, \mathrm{Mn}_{7} \mathrm{SiO}_{12}{ }^{*}, \mathrm{Mn}_{3} \mathrm{Al}_{2}\left(\mathrm{SiO}_{4}\right)_{3}, \text { amorphous }\end{array}$ \\
\hline Braunite & $\mathrm{Mn}_{7} \mathrm{SiO}_{12},(\mathrm{Ca}, \mathrm{Mn}) \mathrm{O}$, unidentified & $(\mathrm{Mn}, \mathrm{Fe})_{2} \mathrm{O}_{3} / \mathrm{Fe}_{2} \mathrm{O}_{3} / \mathrm{Mn}_{2} \mathrm{O}_{3}{ }^{*},(\mathrm{Ca}, \mathrm{Mn}) \mathrm{O}$ \\
\hline Morro da Mina & $(\mathrm{Mn}, \mathrm{Fe})_{3} \mathrm{O}_{4}, \mathrm{Fe}_{3} \mathrm{O}_{4}, \mathrm{Mn}_{7} \mathrm{SiO}_{12}, \mathrm{SiO}_{2}$, unidentified & $\mathrm{Fe}_{3} \mathrm{O}_{4}, \mathrm{Mn}_{7} \mathrm{SiO}_{12}$, unidentified \\
\hline
\end{tabular}

a minor role. This is probably different for an industrial unit, where the influence of mechanical stresses is higher. However, the right ratio of mechanical and chemical stress is difficult to quantify for units of different size. Therefore, it is stressed that the two attrition rates, "jet cup" and "observed under redox conditions in $300 \mathrm{~W}$ unit", can be used to compare different materials, but they should not be used to make predictions of particles lifetime in industrial fluidized-bed units.

Table 6 shows an overview of different particle properties before, during and after operation in the $300 \mathrm{~W}$ unit.

The degradation of particles was highest for Tshipi ore. After $17 \mathrm{~h}$ of fuel operation, nearly $20 \mathrm{wt} \%$ of the recovered material was smaller than $45 \mu \mathrm{m}$ and $10 \mathrm{wt} \%$ of the inserted material could not be recovered at all. Hence, the fraction of fines could potentially be as high as $30 \mathrm{wt} \%$.

For Guizhou ore and Braunite ores, both fines production during experiments as well as measured attrition index were very low. Guizhou ore is the only material whose bulk density increased during the experiments and Braunite ore is one of only two materials (the other being Elwaleed C), where particle size increased during the experiments.

After only a few hours of fuel operation, problems occurred with Morro da Mina particles with respect to circulation: In short intervals the circulation of particles ceased and had to be restarted through mechanical stimulation. Sooner or later this happens to most materials tested in the $300 \mathrm{~W}$ unit, but with the Morro da Mina ore problems with circulation occurred quite early in the test campaign. Such problems are typical for the $300 \mathrm{~W}$ unit and are likely due to an imperfect separation of fines; instead of being elutriated from the process, fines accumulate in the reactor and deteriorate the flowability of solids, which, eventually, can lead to a stop in circulation.

The measured attrition indices are similar for all materials in used state, with the exception for Elwaleed $\mathrm{C}$ ore, which shows a lower resistance.

Considering all the above mentioned properties, Guizhou ore and Braunite ore exhibit the highest resistance to both chemical and mechanical stresses.

\subsection{Solids Circulation}

The circulation of solids was determined using two different methods, which were conducted during the reoxidation of oxygen carrier in the fuel reactor and injection of coal particles in the fuel reactor, respectively, cf. Section 3.2. The coal injection method was performed for two of the ores tested prior to experiments with biomass volatiles. The reoxidation method, on the other hand, was performed each time the reactor was shut down, i.e., usually once per experimental day. For the coal injection method, different gas velocities were tested in order to determine a relation between solids circulation and fluidization velocity. The reoxidation method, however, was performed with the actual gas velocity used during operation.

A general uncertainty with both methods is that the particle properties change during operation, especially size distribution and density, cf. Table 6. Particle properties, however, are only determined for the heat treated particles ("fresh") and for the particles after the experimental campaign ("used"). For the coal injection method it is assumed that particles have properties as in "fresh" state, whereas for the reoxidation method average properties between "fresh" and "used" states are assumed. If the particles undergo drastic changes, as was the case for all ores with the exception of Guizhou, then the uncertainty in these measurements will be high. This variation can also be seen in fuel conversion, e.g., Figure 5; the data points for Guizhou ore exhibit a linear behavior with much less variation than the other materials tested.

Because of the significant changes in the physical properties of the materials, the reoxidation method is better suited for describing circulation during operation. The results from the coal injection method are used to confirm the order of magnitude of solids circulation. Table 7 shows a summary of solids circulation and degree of mass-based conversion determined through the reoxidation method for all ores investigated. A general observation is that the variation in circulation for similar gas velocities is large and that nearly all circulation values determined are similar. Solids circulation with Guizhou, Braunite and Morro da Mina ores was in the order of $1-2 \mathrm{~kg} / \mathrm{m}^{2} \mathrm{~s}$ and somewhat higher with Elwaleed $\mathrm{C}$ and Tshipi, i.e., 0.5$4 \mathrm{~kg} / \mathrm{m}^{2} \mathrm{~s}$. 
Table 6: Particle properties measured before, during and after operation.

\begin{tabular}{|c|c|c|c|c|c|c|}
\hline & & Elwaleed C & Tshipi & Guizhou & Braunite & Morro da Mina \\
\hline $\begin{array}{l}\text { Harmonic mean particle size } \\
\text { (before/ after operation) [change] }\end{array}$ & $(\mu \mathrm{m})$ & $\begin{array}{c}141 / 143 \\
{[+1 \%]}\end{array}$ & $\begin{array}{l}134 / 85 \\
{[-37 \%]}\end{array}$ & $\begin{array}{c}122 / 113 \\
{[-7 \%]}\end{array}$ & $\begin{array}{c}148 / 160 \\
{[+8 \%]}\end{array}$ & $\begin{array}{c}137 / 116 \\
{[-15 \%]}\end{array}$ \\
\hline $\begin{array}{l}\text { Poured bulk density* } \\
\text { (before / after operation) [change] }\end{array}$ & $\left(\mathrm{kg} / \mathrm{m}^{3}\right)$ & $\begin{array}{c}1640 / 1330 \\
{[-19 \%]}\end{array}$ & $\begin{array}{c}1410 / 940 \\
{[-33 \%]}\end{array}$ & $\begin{array}{c}1380 / 1520 \\
{[+10 \%]}\end{array}$ & $\begin{array}{c}1940 / 1550 \\
{[-20 \%]}\end{array}$ & $\begin{array}{c}1360 / 1130 \\
{[-17 \%]}\end{array}$ \\
\hline Average attrition rate ${ }^{\dagger}$ & $(\mathrm{wt} \% / \mathrm{h})$ & 0.29 & 1.18 & 0.05 & 0.12 & 0.87 \\
\hline $\begin{array}{l}\text { Attrition index } \\
\text { (before / after operation) }\end{array}$ & $(\mathrm{wt} \% / \mathrm{h})$ & $4.0 / 7.6$ & $4.7 / 3.4$ & $7.7 / 2.6$ & $1.2 / 3.2$ & $2.2 / 1.8$ \\
\hline
\end{tabular}

${ }^{*}$ measured on the basis of ISO 3923-1 $\quad{ }^{\dagger}$ observed under redox conditions in $300 \mathrm{~W}$ unit $\quad{ }^{\ddagger}$ measured in a customized jet-cup attrition rig [40]

Table 7: Solids circulation and degree of mass-based conversion for all examined ores determined through reoxidation method.

\begin{tabular}{|c|c|c|c|c|c|c|}
\hline & & Elwaleed C & Tshipi & Guizhou & Braunite & Morro da Mina \\
\hline No. of measurements & $(-)$ & 7 & 5 & 4 & 7 & 2 \\
\hline Dimensionless slip velocity, $u_{\text {slip }}^{*}$ & $(-)$ & $0.7 \ldots 1.0$ & $2.2 \ldots 2.3$ & $1.2 \ldots 1.4$ & $0.3 \ldots 0.4$ & 1.3 \\
\hline $\begin{array}{l}\text { Degree of mass-based } \\
\text { conversion [average], } \omega\end{array}$ & $(\operatorname{mass} \%)$ & $\begin{array}{c}94.0 \ldots 99.2 \\
{[97.4]}\end{array}$ & $\begin{array}{c}96.8 \ldots 99.4 \\
{[98.0]}\end{array}$ & $\begin{array}{c}98.1 \ldots 98.6 \\
{[98.4]}\end{array}$ & $\begin{array}{c}98.1 \ldots 98.8 \\
{[98.4]}\end{array}$ & $\begin{array}{c}98.4 \ldots 98.9 \\
{[98.7]}\end{array}$ \\
\hline $\begin{array}{l}\text { Solids circulation* } \\
\text { [average] }\end{array}$ & $\left(\mathrm{kg} / \mathrm{m}^{2} \mathrm{~s}\right)$ & $\begin{array}{c}0.5 \ldots 3.6 \\
{[1.8]}\end{array}$ & $\begin{array}{c}0.6 \ldots 3.3 \\
{[1.9]}\end{array}$ & $\begin{array}{c}1.0 \ldots 1.7 \\
{[1.3]}\end{array}$ & $\begin{array}{c}1.1 \ldots 2.0 \\
{[1.4]}\end{array}$ & $\begin{array}{c}1.0 \ldots 1.7 \\
{[1.4]}\end{array}$ \\
\hline Estimated no. of redox cycles & $(-)$ & 280 & 180 & 280 & 230 & 80 \\
\hline
\end{tabular}

*based on the cross-sectional area of the riser section (AR)

\section{Discussion}

Manganese ores have a number of possible phases which could be of interest for CLOU. Sundqvist et al. identified ( $\mathrm{Mn}, \mathrm{Fe})_{2} \mathrm{O}_{3}$ (bixbyite), ( $\mathrm{Mn}, \mathrm{Fe})_{3} \mathrm{O}_{4}$ (spinel), $\mathrm{Mn}_{7} \mathrm{SiO}_{12}$ (braunite), $\mathrm{CaMn}_{2} \mathrm{O}_{4}$ (marokite) and $\mathrm{SiO}_{2}$ (quartz) when performing XRD analyses of eleven different manganese ores, including Tshipi, Guizhou, Elwaleed $\mathrm{C}$ and Braunite ores [24, 32]. The possibility of a CLOU effect in natural materials can be an advantage with respect to fuel conversion. There has been a limited number of studies around these types of materials, especially with respect to investigations in continuous units. In this work, however, five different types of ore have been investigated with a number of important fuels.

Guizhou ore and Braunite ore exhibit the highest resistance to both chemical and mechanical stresses. The comparison of the attrition resistances of these two materials with the corresponding values of ilmenite sets this work in a broader context. Ilmenite is a well-investigated mineral material that consists mainly of iron-titanium oxides. Two test campaigns were carried out with ilmenite in the same laboratory-scale reactor that was used in this work [41]. The fuels used in those two campaigns were a sulphur-free and a sulphurous kerosene, which were evaporated prior to feeding. The average attrition rates observed under redox conditions were $0.04 \mathrm{wt} \% / \mathrm{h}$ and $0.08 \mathrm{wt} \% / \mathrm{h}$ during $35 \mathrm{~h}$ and $38 \mathrm{~h}$ of fuel addition, respectively. These values are similar to the ones determined for Guizhou ore and Braunite ore. The attrition index measured in a customized jet-cup attrition rig for fresh and used ilmenite particles was $0.3 \mathrm{wt} \% / \mathrm{h}$ and $5.5 \mathrm{wt} \% / \mathrm{h}$, respectively. Ilmenite particles that were used in a larger CLC unit during $67 \mathrm{~h}$ of redox conditions yielded an attrition index of 4.0-4.1 wt\%/h [42]. Hence, the attrition index of ilmenite particles is much lower for fresh material and somewhat higher for the used material as compared to the manganese ores Guizhou and Braunite.

The different manganese ores tested underwent clear changes in their mechanical and chemical properties, cf. Table 6 and Figure 3. It is not clear whether these transformations occurred around a specific point in time during operation or over the entire operation period, and whether the materials assumed a final state or not. Moreover, the nature of transformation is likely to vary from material to material. For instance, the CLOU properties recorded with Elwaleed C ore, see Figure 3, seem to change over the entire test period, i.e., $26 \mathrm{~h}$ of fuel operation. It seems likely that transformations in the crystal structure as well as changes in the physical structure of the materials, e.g., porosity, are connected to operation temperature and/or oxygen-carrier reduction. However, with the data available, this cannot be further analyzed. It should be mentioned that the occurrence of transformations in the crystal structure implies that the order is relevant, in which the different fuels were investigated with each oxygen-carrier material, i.e., (1) biomass volatiles, (2) methane, (3) syngas.

The composition of manganese ores varies significantly as was shown in this and other studies [23, 24, 43]. Therefore, it is important to understand why certain ores perform better than others in a chemical-looping combustion context. Due to the large number of constituents, such an understanding requires statistical methods, e.g., principal component analysis or multivariate analysis, that can show relations between the composition of a material and its chemical-looping combustion related properties, e.g., reactivities towards $\mathrm{CO}$ and $\mathrm{CH}_{4}$ as well as attrition resistance. Such a statistical evaluation would become 


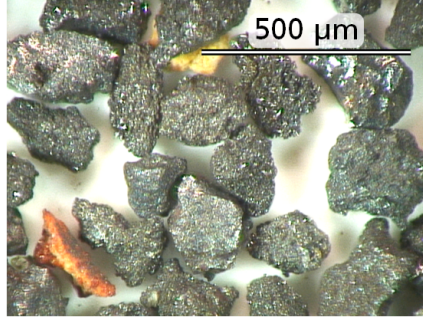

(a) Elwaleed C, inserted

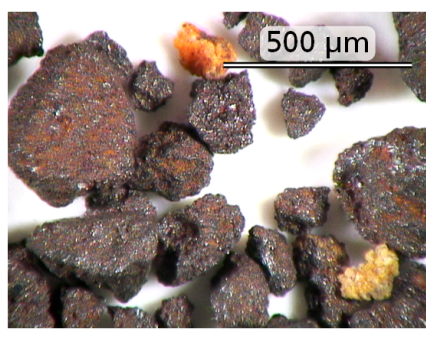

(c) Tshipi, inserted

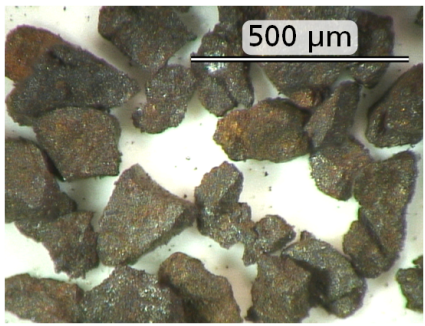

(e) Guizhou, inserted

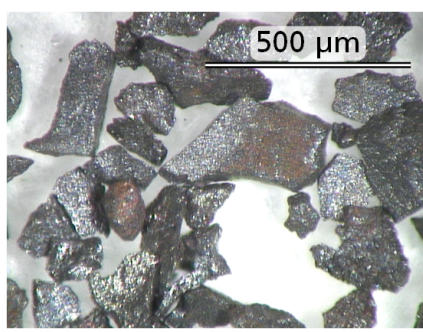

(g) Braunite, inserted

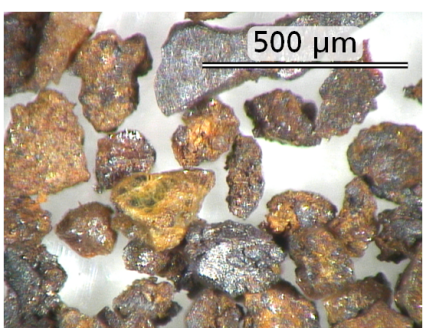

(i) Morro da Mina, inserted

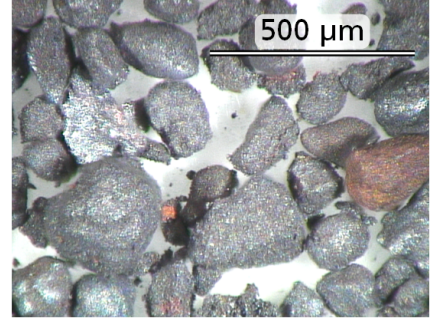

(b) Elwaleed C, recovered

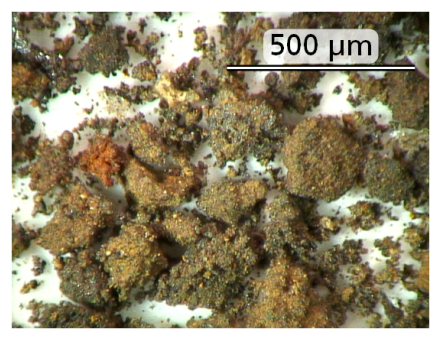

(d) Tshipi, recovered

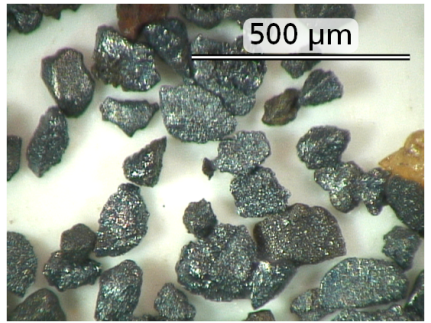

(f) Guizhou, recovered

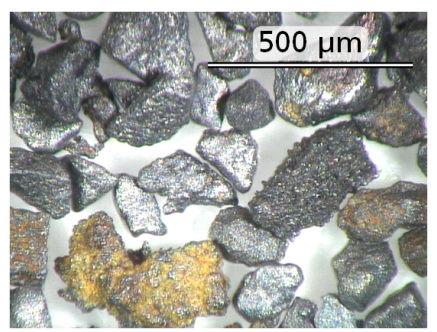

(h) Braunite, recovered

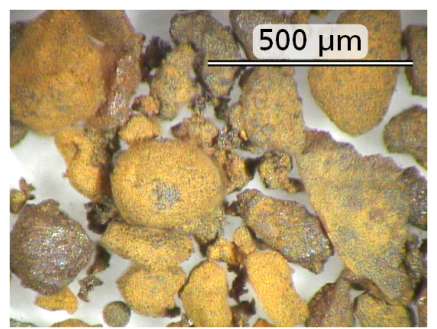

(j) Morro da Mina, recovered
Figure 8: Light microscope images of all manganese ores as inserted in (heat treated and size fraction according to Table 4) and recovered from (unsieved) the $300 \mathrm{~W}$ CLC reactor.

much clearer to interpret if the materials are tested under similar condition, i.e., testing in a bench-scale batch fluidized-bed reactor seems reasonable. On the basis of the experiments per- formed here, it was attempted to detect relations between material composition and performance using a single linear regression model. The predictors used were the ten elements listed in Table 1, and as responses were used the mechanical attrition rate, the redox attrition rate and the $\mathrm{CO}_{2}$ yield with biomass volatiles, see Table 8 . All predictors were tested against each other as well as against each of the responses. No clear correlations could be identified, which is likely due to the small sample number, i.e., only five ores were tested. Furthermore, types and quantities of the phases formed during the initial heat treatment seem to be better suited as predictors than the elemental composition. As most ores are by nature heterogeneous, any oxygen-carrier material produced from an ore will contain particles of substantial variation with respect to chemical phases. Consequently, it is difficult to establish an average phase composition for a given material without investigating a large number of particles. This could for example be done using the QEMSCAN method [44].

Although the results are overall very promising, the experimental facility used in this study was small and it is not reasonable to extrapolate the results to full-scale, where both the velocities and the residence times are higher. In particular, investigations concerning the mechanical stability of oxygen carriers in a CLC environment may largely depend on the utilized velocities. Consequently, experiments at larger scale, e.g., $10 \mathrm{~kW}$ or $100 \mathrm{~kW}$, with operating conditions resembling those in fullscale combustors, will be necessary to obtain information about the lifetime and associated cost of the oxygen carrier more pertinent to a full-scale unit.

\section{Summary and Conclusions}

In this work, five manganese ores have been evaluated in a continuous CLC reactor. The properties with respect to reactivity and mechanical stability varied in a wide range. Table 8 shows an overview of the key characteristics for all manganese ores tested.

- Elwaleed C ore has good fuel conversion properties but low chemical and mechanical stabilities.

- Tshipi ore has good fuel conversion properties, but the lowest lifetime under continuous redox conditions of the investigated materials. If this material is available at a low enough price, it could still be a promising candidate for chemical-looping combustion in a large-scale reactor, where fines can be efficiently separated from the process.

- Guizhou ore seems to have the best overall properties, with a combination of low attrition and very good reactivity.

- Braunite ore exhibited a mediocre reactivity towards biomass volatiles, which might improve at higher gas velocities in the riser and higher rates of solids circulation, respectively.

- Morro da Mina ore has the lowest fuel conversion properties for biomass volatiles, which might be related to its nearly negligible oxygen release properties. Problems 
Table 8: Performance indicators for all five manganese ores tested.

\begin{tabular}{|c|c|c|c|c|c|c|}
\hline & & Elwaleed C & Tshipi & Guizhou & Braunite & Morro da Mina \\
\hline Mechanical attrition rate* & $(\mathrm{wt} \% / \mathrm{h})$ & 7.6 & 3.4 & 1.3 & 1.4 & 1.4 \\
\hline Redox attrition rate $^{\dagger}$ & $(\mathrm{wt} \% / \mathrm{h})$ & 0.3 & 1.2 & 0.05 & 0.1 & 0.9 \\
\hline $\mathrm{CO}_{2}$ yield with biomass volatiles & $(\mathrm{mol} \%)$ & 93 & 94 & 90 & 78 & 67 \\
\hline $\mathrm{CO}_{2}$ yield with methane ${ }^{\S}$ & $(\mathrm{mol} \%)$ & 62 & - & 72 & 59 & - \\
\hline $\mathrm{CO}_{2}$ yield with syngas" & $(\mathrm{mol} \%)$ & 92 & 97 & 97 & 98 & - \\
\hline $\mathrm{O}_{2}$ released ${ }^{\mathrm{TI}}$ & $(\operatorname{vol} \%)$ & $0.5 \ldots 2.5$ & 1 & 3 & $0.5 \ldots 3$ & $<0.5$ \\
\hline Average oxygen carrier circulation & $\left(\mathrm{kg} / \mathrm{m}^{2} \mathrm{~s}\right)$ & 1.8 & 1.9 & 1.3 & 1.4 & 1.4 \\
\hline
\end{tabular}

with fluidization in the $300 \mathrm{~W}$ unit led to the lowest fuel operation time in the field. Such difficulties with fluidization are likely to be irrelevant for fluidized-bed combustors larger than the $300 \mathrm{~W}$ unit.

In this work, it could be shown that chemical-looping combustion of biomass volatiles, i.e., the main constituent of biomass fuels, is technically feasible using low-cost manganese minerals as oxygen carrier. This is a significant finding, as it is likely that natural materials would likely be needed for a cost-effective process. However, the properties of the five manganese ores investigated differed significantly and, hence, it is likely that other ores exist that are even better suited for converting biomass and biomass volatiles in a chemical-looping fluidized-bed application. Notably, the conversion of the fuel was very high for at least three of the materials. All of the manganese ores also showed some oxygen uncoupling, which could be an advantage in large boilers, with inadequate mixing. The resistance to chemical and mechanical stresses of two of the materials was higher than for the other manganese ores tested, and their attrition was similar to that of the iron-titanium-based mineral ilmenite.

In conclusion, this study has shown that it is possible to remove $\mathrm{CO}_{2}$ efficiently from the atmosphere through a chemical-looping combustion process with biomass as fuel. However, some manganese ores are better suited than others with respect to reactivity and lifetime. Ageing of the materials as a function of redox cycles was found to have a clear but varying influence on the particles' physical properties as well as on the phase composition. The latter is likely to affect fuel conversion, but it is difficult to quantify due to heterogeneous structures and the large number of elements present. The presence of $(\mathrm{Mn}, \mathrm{Fe})_{2} \mathrm{O}_{3}$ (bixbyite) seems to be beneficial for the release of oxygen, while $\mathrm{Mn}_{7} \mathrm{SiO}_{12}$ (braunite) tends to decompose during redox operation. With respect to conversion of methane and $\mathrm{C} 2$ species, increasing the temperature was found to have a strong positive effect. No C3 species were detected, even at temperatures as low as $850^{\circ} \mathrm{C}$.

\section{Nomenclature}

$\begin{array}{ll}a & (-) \\ f_{\mathrm{C} i} & (\mathrm{~mol} / \mathrm{mol})\end{array}$

$m \quad(\mathrm{~kg})$

$m_{\text {bed,FR }} \quad(\mathrm{kg})$

$m_{\mathrm{OC}, \mathrm{ox}} \quad(\mathrm{kg})$

$\dot{m}_{\mathrm{s}} \quad(\mathrm{kg} / \mathrm{s})$

$N \quad(-)$

$t \quad(\mathrm{~s})$

$\begin{array}{ll}T & \left({ }^{\circ} \mathrm{C}\right)\end{array}$

$u_{0} \quad(\mathrm{~m} / \mathrm{s})$

$u_{\text {slip }} \quad(\mathrm{m} / \mathrm{s})$

$u_{\mathrm{slip}}^{*} \quad(-)$

$u_{\mathrm{t}} \quad(\mathrm{m} / \mathrm{s})$

$x_{i} \quad(\mathrm{~mol} / \mathrm{mol})$

pre-exponential factor

carbon fraction of $i\left(\mathrm{CO}, \mathrm{CH}_{4}\right.$, $\mathrm{C} 2$ or C3), Eqs. (2)-(5)

mass

bed mass in fuel reactor

mass of oxygen carrier in the most oxidized state

mass flow of solids, Eqs. (9) \& (11)

theoretic number of continuously stirred-tank reactors (CSTR) in series

time

temperature

superficial gas velocity

slip velocity, i.e., relative velocity between gas and particle dimensionless slip velocity terminal velocity based on average values of particle size and density

concentration of species $i$

$\gamma_{\mathrm{CO} 2} \quad(\mathrm{~mol} / \mathrm{mol}) \quad \mathrm{CO}_{2}$ yield or carbon fraction of $\mathrm{CO}_{2}$, Eq. (1)

$\Delta \dot{m}_{\mathrm{O}_{2}, \mathrm{AR}} \quad(\mathrm{kg} / \mathrm{s})$

$\tau$

(s)

$\omega \quad(\mathrm{kg} / \mathrm{kg})$ mass of oxygen consumed by the oxygen carrier in the air reactor during (continuous) fuel operation

total residence time of an average particle in a series of $N$ CSTRs

degree of mass-based conversion, Eq. (8) 


\begin{tabular}{|c|c|}
\hline AR & air reactor \\
\hline BECCS & $\begin{array}{l}\text { bio-energy carbon capture and stor- } \\
\text { age }\end{array}$ \\
\hline CCS & carbon capture and storage \\
\hline CLC & chemical-looping combustion \\
\hline CLOU & $\begin{array}{l}\text { chemical-looping combustion with } \\
\text { oxygen uncoupling }\end{array}$ \\
\hline CSTR & continuously stirred-tank reactor \\
\hline FR & fuel reactor \\
\hline ICP-SFMS & $\begin{array}{l}\text { inductively coupled plasma-sector } \\
\text { field mass spectrometry }\end{array}$ \\
\hline LOI & $\begin{array}{l}\text { loss on ignition, i.e., mass loss upon } \\
\text { heating to } 1000^{\circ} \mathrm{C}\end{array}$ \\
\hline $\mathrm{M}_{x} \mathrm{O}_{y}$ & oxidized metal oxide \\
\hline $\mathrm{M}_{x} \mathrm{O}_{y-1}$ & reduced metal oxide \\
\hline TGA & thermo-gravimetric analyzer \\
\hline XRD & X-ray (powder) diffraction \\
\hline
\end{tabular}

\section{Acknowledgements}

The study is carried out under the project "Kemcyklisk förbränning (CLC) av biomassa för att avlägsna koldioxid från atmosfären" (Project 14-379) financed by Stiftelsen ÅFforsk. Additional funding was received from the European Research Council (ERC) under the European Union's Seventh Framework Programme (FP7/2007-2013) (Grant Agreement No 291235). Special thanks to Viktor Stenberg and Max Biermann for both company and helping hands during the experiments.

\section{References}

[1] IPCC, IPCC Special Report on Carbon Dioxide Capture and Storage. Prepared by Working Group III of the Intergovernmental Panel on Climate Change, Cambridge University Press, Cambridge, UK and New York, NY, USA, 2005.

[2] C. Azar, D. Johansson, N. Mattsson, Meeting global temperature targets - The role of bioenergy with carbon capture and storage, Environmental Research Letters 8 (3).

[3] C. Ekström, F. Schwendig, O. Biede, F. Franco, G. Haupt, G. de Koeijer, C. Papapavlou, P. Røkke, Techno-Economic Evaluations and Benchmarking of Pre-combustion $\mathrm{CO}_{2}$ Capture and Oxy-fuel Processes Developed in the European ENCAP Project, in: Proceedings of the $9^{\text {th }}$ International Conference on Greenhouse Gas Control Technologies, Washington DC, USA, 2009.

[4] J. Abanades, B. Arias, A. Lyngfelt, T. Mattisson, D. Wiley, H. Li, M. Ho, E. Mangano, S. Brandani, Emerging $\mathrm{CO}_{2}$ capture systems, International Journal of Greenhouse Gas Control 40 (2015) 126-166.

[5] IPCC, Climate Change 2014: Synthesis Report. Contribution of Working Groups I, II and III to the Fifth Assessment Report of the Intergovernmental Panel on Climate Change, Cambridge University Press, Geneva, Switzerland, 2014.

[6] A. Lyngfelt, Chemical-looping combustion of solid fuels - Status of development, Applied Energy 113 (2014) 1869-1873.

[7] P. Moldenhauer, M. Rydén, T. Mattisson, A. Lyngfelt, Chemical-looping combustion and chemical-looping with oxygen uncoupling of kerosene with $\mathrm{Mn}$ - and $\mathrm{Cu}$-based oxygen carriers in a circulating fluidized-bed 300 W laboratory reactor, Fuel Processing Technology 104 (2012) 378389.

[8] H. Leion, T. Mattisson, A. Lyngfelt, Use of Ores and Industrial Products as Oxygen Carriers in Chemical-Looping Combustion, Energy \& Fuels 23 (4) (2009) 2307-2315.
[9] A. Fossdal, E. Bakken, B. Øye, C. Schøning, I. Kaus, T. Mokkelbost, Y. Larring, Study of inexpensive oxygen carriers for chemical looping combustion, International Journal of Greenhouse Gas Control 5 (3) (2011) 483-488.

[10] C. Linderholm, A. Lyngfelt, A. Cuadrat, E. Jerndal, Chemical-looping combustion of solid fuels - Operation in a $10 \mathrm{~kW}$ unit with two fuels, above-bed and in-bed fuel feed and two oxygen carriers, manganese ore and ilmenite, Fuel 102 (2012) 808-822.

[11] C. Linderholm, A. Lyngfelt, C. Dueso, Chemical-looping combustion of solid fuels in a $10 \mathrm{~kW}$ reactor system using natural minerals as oxygen carrier, in: Proceedings of the 11th International Conference on Greenhouse Gas Control Technologies, Kyoto, Japan, 598-607, 2013.

[12] M. Schmitz, C. Linderholm, P. Hallberg, S. Sundqvist, A. Lyngfelt, Chemical-Looping Combustion of Solid Fuels Using Manganese Ores as Oxygen Carriers, Energy \& Fuels 30 (2) (2016) 1204-1216.

[13] M. Arjmand, H. Leion, A. Lyngfelt, T. Mattisson, Use of manganese ore in chemical-looping combustion (CLC) - Effect on steam gasification, International Journal of Greenhouse Gas Control 8 (2012) 56-60.

[14] P. Frohn, M. Arjmand, G. Azimi, H. Leion, T. Mattisson, A. Lyngfelt, On the high-gasification rate of Brazilian manganese ore in chemical-looping combustion (CLC) for solid fuels, AIChE Journal 59 (11) (2013) 43464354.

[15] M. Arjmand, H. Leion, T. Mattisson, A. Lyngfelt, Investigation of different manganese ores as oxygen carriers in chemical-looping combustion (CLC) for solid fuels, Applied Energy 113 (2014) 1883-1894.

[16] M. Keller, H. Leion, T. Mattisson, Mechanisms of Solid Fuel Conversion by Chemical-Looping Combustion (CLC) using Manganese Ore: Catalytic Gasification by Potassium Compounds, Energy Technology 1 (4) (2013) 273-282.

[17] D. Mei, T. Mendiara, A. Abad, L. De Diego, F. García-Labiano, P. Gayán, J. Adánez, H. Zhao, Manganese Minerals as Oxygen Carriers for Chemical Looping Combustion of Coal, Industrial and Engineering Chemistry Research 55 (22) (2016) 6539-6546.

[18] N. Mohammad Pour, G. Azimi, H. Leion, M. Rydén, T. Mattisson, A. Lyngfelt, Investigation of Manganese-Iron Oxide Materials based on Manganese Ores as Oxygen Carriers for Chemical Looping with Oxygen Uncoupling (CLOU), Energy Technology 2 (5) (2014) 469-479.

[19] N. M. Pour, G. Azimi, H. Leion, M. Rydén, A. Lyngfelt, Production and examination of oxygen-carrier materials based on manganese ores and $\mathrm{Ca}(\mathrm{OH})_{2}$ in chemical looping with oxygen uncoupling, AIChE Journal 60 (2) (2014) 645-656.

[20] L. Xu, R. Edland, Z. Li, H. Leion, D. Zhao, N. Cai, Cu-Modified Manganese Ore as an Oxygen Carrier for Chemical Looping Combustion, Energy \& Fuels 28 (11) (2014) 7085-7092.

[21] L. Xu, H. Sun, Z. Li, N. Cai, Experimental study of copper modified manganese ores as oxygen carriers in a dual fluidized bed reactor, Applied Energy 162 (2016) $940-947$.

[22] S. Haider, G. Azimi, L. Duan, E. Anthony, K. Patchigolla, J. Oakey, H. Leion, T. Mattisson, A. Lyngfelt, Enhancing properties of iron and manganese ores as oxygen carriers for chemical looping processes by dry impregnation, Applied Energy 163 (2016) 41-50.

[23] S. Sundqvist, M. Arjmand, T. Mattisson, M. Rydén, A. Lyngfelt, Screening of different manganese ores for chemical-looping combustion (CLC) and chemical-looping with oxygen uncoupling (CLOU), International Journal of Greenhouse Gas Control 43 (2015) 179-188.

[24] S. Sundqvist, N. Khalilian, H. Leion, T. Mattisson, A. Lyngfelt, Manganese ores as oxygen carriers for chemical-looping combustion (CLC) and chemical-looping with oxygen uncoupling (CLOU), Journal of Environmental Chemical Engineering 5 (3) (2017) 2552-2563.

[25] Y. Larring, M. Pishahang, M. F. Sunding, K. Tsakalakis, Fe-Mn based minerals with remarkable redox characteristics for chemical looping combustion, Fuel 159 (2015) 169 - 178.

[26] E. Ksepko, P. Babiński, L. Nalbandian, The redox reaction kinetics of Sinai ore for chemical looping combustion applications, Applied Energy 190 (2017) 1258-1274.

[27] D. Mei, T. Mendiara, A. Abad, L. De Diego, F. García-Labiano, P. Gayán, J. Adánez, H. Zhao, Evaluation of Manganese Minerals for Chemical Looping Combustion, Energy \& Fuels 29 (10) (2015) 6605-6615.

[28] P. Perreault, S. Rifflart, E. Nguyen, G.-S. Patience, Pyrolusite: An alternative oxygen carrier for chemical looping combustion, Fuel 185 (2016) 630-638. 
[29] C. Linderholm, M. Schmitz, M. Biermann, M. Hanning, A. Lyngfelt, Chemical-looping combustion of solid fuel in a $100 \mathrm{~kW}$ unit using sintered manganese ore as oxygen carrier, International Journal of Greenhouse Gas Control 65 (2017) 170 - 181.

[30] C. Linderholm, A. Lyngfelt, M. Rydén, M. Schmitz, Chemical-looping combustion of biomass in a $100 \mathrm{~kW}$ pilot, in: Proceedings of the $25^{\text {th }} \mathrm{Eu}-$ ropean Biomass Conference and Exhibition (EUBCE), Stockholm, Sweden, 2017.

[31] C. Linderholm, M. Schmitz, P. Knutsson, A. Lyngfelt, Chemical-looping combustion in a 100-kW unit using a mixture of ilmenite and manganese ore as oxygen carrier, Fuel 166 (2016) 533-542.

[32] S. Sundqvist, T. Mattisson, Manganese Ore Screening and Solid Fuel testing, in: Proceedings of the $4^{\text {th }}$ International Conference on Chemical Looping, Nanjing, China, 2016.

[33] A. Larsson, M. Israelsson, F. Lind, M. Seemann, H. Thunman, Using ilmenite to reduce the tar yield in a dual fluidized bed gasification system, Energy \& Fuels 28 (4) (2014) 2632-2644.

[34] W. Haynes, T. J. Bruno, D. R. Lide (Eds.), CRC Handbook of Chemistry and Physics - Internet Version 2016, CRC Press, Boca Raton, FL, USA, $96^{\text {th }}$ edn., 2016.

[35] D. Kunii, O. Levenspiel, Fluidization engineering, ButterworthHeinemann, Boston, MA, USA, $2^{\text {nd }}$ edn., 1991.

[36] P. Markström, N. Berguerand, A. Lyngfelt, The application of a multistage-bed model for residence-time analysis in chemical-looping combustion of solid fuel, Chemical Engineering Science 65 (18) (2010) 5055-5066.

[37] G. Azimi, H. Leion, M. Rydén, T. Mattisson, A. Lyngfelt, Investigation of different $\mathrm{Mn}-\mathrm{Fe}$ oxides as oxygen carrier for chemical-looping with oxygen uncoupling (CLOU), Energy \& Fuels 27 (1) (2013) 367-377.

[38] G. Azimi, T. Mattisson, H. Leion, M. Rydén, A. Lyngfelt, Comprehensive study of Mn-Fe-Al oxygen-carriers for chemical-looping with oxygen uncoupling (CLOU), International Journal of Greenhouse Gas Control 34 (2015) 12-24.

[39] M. Hanning, V. Frick, T. Mattisson, M. Rydén, A. Lyngfelt, Performance of Combined Manganese-Silicon Oxygen Carriers and Effects of Including Titanium, Energy \& Fuels 30 (2) (2016) 1171-1182.

[40] M. Rydén, P. Moldenhauer, S. Lindqvist, T. Mattisson, A. Lyngfelt, Measuring attrition resistance of oxygen carrier particles for chemical looping combustion with a customized jet cup, Powder Technology 256 (2014) 75-86.

[41] P. Moldenhauer, M. Rydén, T. Mattisson, M. Younes, A. Lyngfelt, The use of ilmenite as oxygen carrier with kerosene in a $300 \mathrm{~W}$ CLC laboratory reactor with continuous circulation, Applied Energy 113 (2014) 18461854.

[42] P. Moldenhauer, M. Rydén, T. Mattisson, A. Hoteit, A. Jamal, A. Lyngfelt, Chemical-Looping Combustion with Fuel Oil in a $10 \mathrm{~kW}$ Pilot Plant, Energy \& Fuels 28 (9) (2014) 5978-5987.

[43] B. Sorensen, S. Gaal, E. Ringdalen, M. Tangstad, R. Kononov, O. Ostrovski, Phase compositions of manganese ores and their change in the process of calcination, International Journal of Mineral Processing 94 (34) (2010) $101-110$.

[44] K. Hoal, J. Stammer, S. Appleby, J. Botha, J. Ross, P. Botha, Research in quantitative mineralogy: Examples from diverse applications, Minerals Engineering 22 (4) (2009) 402-408. 